Review

\title{
Small Molecules as Modulators of Voltage-Gated Calcium Channels in Neurological Disorders: State of the Art and Perspectives
}

\author{
Stefano Lanzetti (D) and Valentina Di Biase *(D)
}

Citation: Lanzetti, S.; Di Biase, V. Small Molecules as Modulators of Voltage-Gated Calcium Channels in Neurological Disorders: State of the Art and Perspectives. Molecules 2022, 27, 1312. https://doi.org/10.3390/ molecules 27041312

Academic Editors: Letizia Giampietro and Claudio Ferrante

Received: 16 January 2022

Accepted: 11 February 2022

Published: 15 February 2022

Publisher's Note: MDPI stays neutral with regard to jurisdictional claims in published maps and institutional affiliations.

Copyright: (C) 2022 by the authors. Licensee MDPI, Basel, Switzerland. This article is an open access article distributed under the terms and conditions of the Creative Commons Attribution (CC BY) license (https:// creativecommons.org/licenses/by/ $4.0 /)$.
Institute of Pharmacology, Department of Medical Statistics, Informatics and Health Economics, Medical University of Innsbruck, Peter-Mayr Strasse 1, A-6020 Innsbruck, Austria; stefano.lanzetti@i-med.ac.at

* Correspondence: valentina.di-biase@i-med.ac.at

\begin{abstract}
Voltage-gated calcium channels (VGCCs) are widely expressed in the brain, heart and vessels, smooth and skeletal muscle, as well as in endocrine cells. VGCCs mediate gene transcription, synaptic and neuronal structural plasticity, muscle contraction, the release of hormones and neurotransmitters, and membrane excitability. Therefore, it is not surprising that VGCC dysfunction results in severe pathologies, such as cardiovascular conditions, neurological and psychiatric disorders, altered glycemic levels, and abnormal smooth muscle tone. The latest research findings and clinical evidence increasingly show the critical role played by VGCCs in autism spectrum disorders, Parkinson's disease, drug addiction, pain, and epilepsy. These findings outline the importance of developing selective calcium channel inhibitors and modulators to treat such prevailing conditions of the central nervous system. Several small molecules inhibiting calcium channels are currently used in clinical practice to successfully treat pain and cardiovascular conditions. However, the limited palette of molecules available and the emerging extent of VGCC pathophysiology require the development of additional drugs targeting these channels. Here, we provide an overview of the role of calcium channels in neurological disorders and discuss possible strategies to generate novel therapeutics.
\end{abstract}

Keywords: voltage-gated calcium channels; small molecules; splice variants; $\mathrm{Ca}_{\mathrm{V}} 1$; $\mathrm{Ca}_{\mathrm{V}} 2$; $\mathrm{Ca}_{\mathrm{V}} 3$; seizure; autism spectrum disorders; anxiety; pain; PYT; Compound 8; gabapentin; pregabalin

\section{Introduction}

Ion channels are the molecular underpinnings of membrane permeability and excitability and are essentially involved in the function of every organ in the body. Over fifty inherited channelopathies are attributed to ion channel dysfunctions [1]. Currently, small molecules targeting ion channels represent $18 \%$ of the drugs approved by the Food and Drug Administration, highlighting the importance of ion channels in clinical pharmacology [2]. The aberrant expression of VGCCs, mutations in their amino acid sequence, and altered post-transcriptional regulation are associated with several brain disorders and comorbidities [3-12]. Small molecules directed at VGCCs available in medical practice include blockers, some of which lack the selectivity to channels' isoforms and cause pronounced side effects. These inhibitors are not sufficient to treat VGCC-dependent diseases. Therefore, new molecules targeting VGCCs need to be identified and characterized on channel-mediated functions. In this manuscript, we discuss the impact of alternative splicing on channel drug sensitivity, the importance of restoring proper calcium current kinetics in dysfunctional channels, and the efficacy of selective blockers in the treatment of pain and seizure. Furthermore, preclinical findings show that several small molecules that are in use for specific conditions of VGCCs may be potential candidates for additional applications. We report some compounds exhibiting isoform selectivity or the ability to offset aberrant signaling pathways downstream of calcium channel mutants that are associated with diseases. Ideally, innovative molecules should selectively target only those 
channels involved in pathological processes, while sparing those participating in normal functions. To this end, understanding the physio-pathological regulation of VGCCs and the underlying molecular and cellular mechanisms is paramount.

\section{Voltage-Gated Calcium Channels}

VGCCs are pore-forming multisubunit complexes that allow calcium influx upon membrane depolarization and control a plethora of tissue-specific processes, including excitation-contraction coupling, neurotransmitter and hormone release, gene transcription, synaptic plasticity, membrane excitability, and cardiac and neuronal pacemaker activity [13]. In the 1980s and early 1990s, VGCCs were classified into L-, N-, P/Q-, and R-types, based on their pharmacological, voltage-dependence, and kinetic properties (Table 1) [13,14]. Long-lasting L-type calcium currents are endowed with a large single-channel conductance and sensitivity to dihydropyridine (DHP), phenylalkylamines, and benzothiazepines [15]. T-type calcium channels activate at low voltages, inactivate rapidly, deactivate slowly, and are characterized by a tiny single-channel conductance $[13,16,17]$. N-type currents were first recorded in dorsal root ganglion neurons; being non-L-type and non-T-type, they were designated as neuronal [16]. N-type calcium currents are inhibited by the snail $\omega$-conotoxin GVIA and the related molecules [18,19]. P-type currents were initially recorded in Purkinje neurons. P-type currents are typically DHP- and $\omega$-conotoxin GVIA-insensitive, and are inhibited by the spider $\omega$-agatoxin IVA $[20,21]$. Q-type currents were originally identified in cerebellar granule neurons. The $\omega$-agatoxin IVA also blocks Q-type calcium currents with a lower affinity than the P-type [22]. These $\omega$-agatoxin IVA-sensitive calcium currents are commonly referred to as P/Q-type. Finally, additional R-type currents were recorded in cerebellar granule neurons and were found to be sensitive to the tarantula toxin SNX482 [23]. However, SNX-482 was later shown to be rather unselective as it also inhibits potassium channels [24].

Table 1. Subtype, function, and disease of calcium channel types.

\begin{tabular}{|c|c|c|c|c|c|}
\hline $\begin{array}{c}\text { Current } \\
\text { Type }\end{array}$ & $\begin{array}{c}\mathrm{Ca} \\
\text { Nomenclature }\end{array}$ & $\begin{array}{l}\text { Specific } \\
\text { Blocker }\end{array}$ & Gene & Main Physiological Role & Disease \\
\hline \multirow{4}{*}{$\mathrm{L}$} & $\mathrm{Ca}_{V} 1.1$ & DHP & CACNA1S & $\begin{array}{l}\text { Excitation-contraction } \\
\text { coupling in skeletal muscle, } \\
\text { regulation of } \\
\text { gene transcription }\end{array}$ & $\begin{array}{l}\text { Hypokalemic periodic paralysis } \\
\text { [5], normokalemic periodic } \\
\text { paralysis; malignant hypothermia } \\
\text { susceptibility [5] }\end{array}$ \\
\hline & $\mathrm{Ca}_{V} 1.2$ & DHP & CACNA1C & $\begin{array}{l}\text { Excitation-contraction } \\
\text { coupling in cardiac muscle, } \\
\text { regulation of gene } \\
\text { transcription, endocrine } \\
\text { secretion, spine and } \\
\text { dendritic calcium signaling } \\
\text { in neurons }\end{array}$ & $\begin{array}{l}\text { Timothy syndrome [25-29], } \\
\text { bipolar disorder [30,31], } \\
\text { depressive disorder [32-34], } \\
\text { schizophrenia [33,35-39], } \\
\text { post-traumatic stress } \\
\text { syndrome [40,41], Brugada } \\
\text { syndrome (\# 611875), cardiac } \\
\text { Long QT syndrome [" } 618447]\end{array}$ \\
\hline & $\mathrm{Ca}_{V} 1.3$ & DHP & CACNA1D & $\begin{array}{l}\text { Hearing, cardiac and } \\
\text { neuronal pace-making } \\
\text { activity, spine and dendritic } \\
\text { calcium signaling } \\
\text { in neurons }\end{array}$ & $\begin{array}{l}\text { Deafness [42,43], autism [44], } \\
\text { bipolar disorder }[45,46] \text {, sinoatrial } \\
\text { dysfunction }\left({ }^{\#} 614896\right)\end{array}$ \\
\hline & $\mathrm{Ca}_{V} 1.4$ & DHP & CACNA1F & Retinal neurotransmission & $\begin{array}{l}\text { Congenital stationary night } \\
\text { blindness [47,48], X-linked } \\
\left.\text { Cone-Rode dystrophy ( }{ }^{\#} 300476\right), \\
\text { Aland Island eye disease } \\
\left({ }^{\#} 300600\right)\end{array}$ \\
\hline
\end{tabular}


Table 1. Cont.

\begin{tabular}{|c|c|c|c|c|c|}
\hline $\begin{array}{l}\text { Current } \\
\text { Type }\end{array}$ & $\begin{array}{c}\mathrm{Ca} \\
\text { Nomenclature }\end{array}$ & $\begin{array}{l}\text { Specific } \\
\text { Blocker }\end{array}$ & Gene & Main Physiological Role & Disease \\
\hline $\mathrm{N}$ & $\mathrm{Ca}_{\mathrm{V}} 2.1$ & $\begin{array}{l}\omega \text {-conotoxin- } \\
\text { GVIA }\end{array}$ & CACNA1A & \multirow{2}{*}{$\begin{array}{l}\text { Neurotransmitter release, } \\
\text { somatodendritic calcium } \\
\text { signaling }\end{array}$} & $\begin{array}{c}\text { Familial hemiplegic } \\
\text { migraine }[49,50], \text { ataxia } \\
\left({ }^{\#} 108500,{ }^{\#} 183086\right)\end{array}$ \\
\hline $\mathrm{P} / \mathrm{Q}$ & $\mathrm{Ca}_{\mathrm{V}} 2.2$ & $\begin{array}{l}\omega \text {-agatoxin- } \\
\text { IVA }\end{array}$ & CACNA1B & & $\begin{array}{c}\text { Pain [8,51-61], } \\
\text { neurodevelopmental } \\
\text { disorder }{ }^{\#} 618497\end{array}$ \\
\hline $\mathrm{R}$ & $\mathrm{Ca}_{V} 2.3$ & SNX-482 & CACNA1E & $\begin{array}{l}\text { Neurotransmitter release, } \\
\text { membrane excitability }\end{array}$ & $\begin{array}{c}\text { Seizure [62-65], } \\
\text { neurodevelopmental } \\
\left.\text { disorder( }{ }^{\#} 618497\right), \\
\text { encephalopathy (\# 618285) }\end{array}$ \\
\hline \multirow{5}{*}{$\mathrm{T}$} & $\mathrm{Ca}_{\mathrm{V}} 3.1$ & $\begin{array}{l}\text { Ethosuximide } \\
\text { Zonisamide }\end{array}$ & CACNA1G & \multirow{3}{*}{$\begin{array}{l}\text { Membrane excitability, } \\
\text { pace-making, firing, } \\
\text { subthreshold oscillations }\end{array}$} & $\begin{array}{l}\text { Seizure [66], spinocerebellar } \\
\left.\text { ataxia (" } 616795 \text { and }{ }^{\#} 618087\right)\end{array}$ \\
\hline & $\mathrm{Ca}_{\mathrm{V}} 3.2$ & $\begin{array}{l}\text { Ethosuximide } \\
\text { Zonisamide }\end{array}$ & CACNA1H & & $\begin{array}{c}\text { Seizure [67-72], autism [73], } \\
\text { pain [51-54], hyperaldosteronism } \\
\left({ }^{\#} \text { 617027) }\right.\end{array}$ \\
\hline & $\mathrm{Ca}_{\mathrm{V}} 3.3$ & $\begin{array}{l}\text { Ethosuximide } \\
\text { Zonisamide }\end{array}$ & CACNA1I & & $\begin{array}{l}\text { Seizure and neurodevelopmental } \\
\text { disorders [74] }\end{array}$ \\
\hline & & \multicolumn{4}{|c|}{$\begin{array}{l}\text { Note: \# indicates the reference number in the "Online Mendelian Inheritance in Man" (OMIM) database } \\
\text { for channelopathies. }\end{array}$} \\
\hline & & \multicolumn{4}{|c|}{ 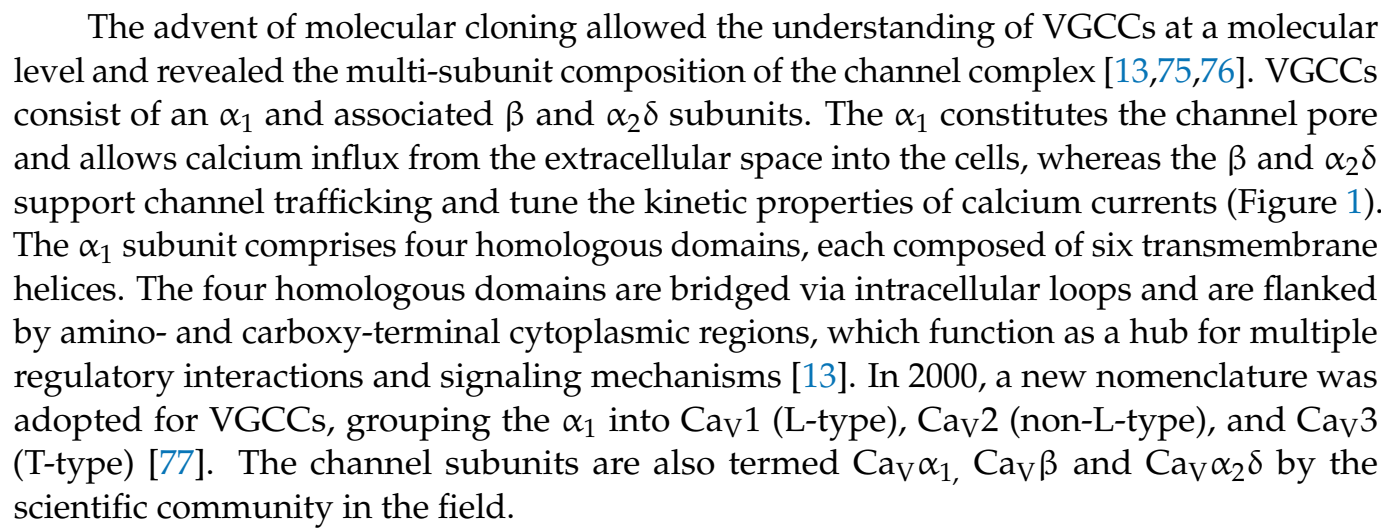 } \\
\hline
\end{tabular}

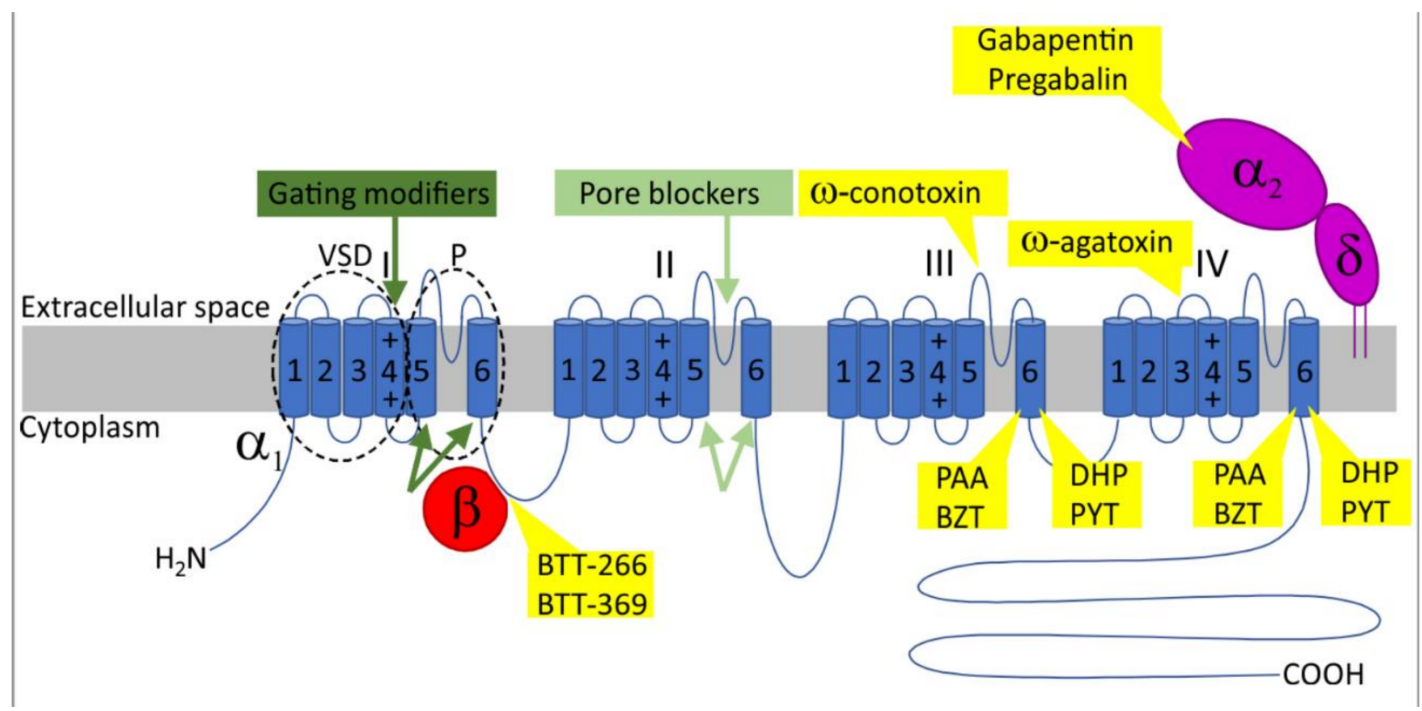

Figure 1. The topology of voltage-gated calcium channels with known drug-binding regions and the mechanisms of channel inhibition. The image represents the channel complex including the $\mathrm{Ca}_{V} \alpha_{1}$ 
pore forming subunit with the auxiliary $\mathrm{Ca}_{V} \beta$ and $\mathrm{Ca}_{\mathrm{V}} \alpha 2 \delta$ which regulate channel trafficking and biophysical properties. The $\mathrm{Ca}_{V} \alpha_{1}$ is organized in four transmembrane domains (I-IV), each containing six membrane-spanning helices (S1-S6). All S5-S6 segments form the channel pore (P) whereas the S1-S4 constitute the voltage-sensing domain (VSD). Inhibition is achieved by modifying channel gating (dark green arrows, gating modifiers) through binding with the extracellular linkers of the VSD (e.g., agatoxin) or with the activation gates of the pore (e.g., DHP). Another blocking mechanism includes the direct occlusion of the pore from the extracellular space (e.g., conotoxin). Small molecules are membrane permeable and can access the pore from the cytoplasm, thereby impeding the ion permeation (light green, pore blockers) (e.g., PAA). BTT-266 and BTT-369 disrupt the $\mathrm{Ca}_{V} \alpha_{1}-\mathrm{Ca}_{V} \beta$ interaction interfering with channel trafficking. Gabapentin and pregabalin reduce channel membrane expression by binding with the $\mathrm{Ca}_{V} \alpha 2 \delta$ subunit. BZT, benzothiazepine; DHP, dihydropyridine; PAA, phenylalkylamine.

\section{Physiological Roles of VGCCs in the Nervous System}

VGCCs are ubiquitously expressed in the nervous system. Isoform diversity and localization confer specific functions to VGCCs [3,14,78-84]. L-type CaV1.2 is the predominant L-VGCCs expressed in the brain and is highly represented in the cardiovascular system $[80,85]$. $\mathrm{Ca}_{\mathrm{V}} 1.2$ channels are localized on the soma and dendrites of most types of neurons, where they control gene expression [86-88], synaptic plasticity [89,90], calciumdependent enzymes, and calcium-activated potassium channels [91]. Cav1.3 channels exhibit a neuronal somatodendritic distribution that is similar to $\mathrm{Ca}_{\mathrm{V}}$ 1.2. These two L-type isoforms are often co-expressed in the same neuronal type [85,92]. Cav1.3 participates in postsynaptic signaling integration and regulates membrane excitability $[3,44,93,94]$. Cav1.3 is also localized at the ribbon synapse of the inner cochlear hair cells, where it controls synaptic release and is necessary for the transmission of impulses to the auditory cortex $[78,95,96]$. Consistently, Cav1.3 knock-out mice and humans expressing dysfunctional non-conducting $\mathrm{Ca}_{V} 1.3$ mutants present with congenital deafness [42,43]. Cav1.4 is predominantly expressed in the rod photoreceptors of the retina. Here, $\mathrm{Ca}_{\mathrm{V}} 1.4$ controls synaptic release and allows the transmission of visual stimuli [79]. Cav1.4 knock-out mice are blind [97]. Mutations inducing loss-of-function in Cav1.4 lead to night blindness in humans [47]. Cav1.1 expression is restricted to the skeletal muscle, where it couples plasmalemma excitation with muscle contraction [5].

$\mathrm{Ca}_{V} 2.1$ and $\mathrm{Ca}_{V} 2.2$ channels localize at the presynapse of nerve cells [78]. Here, they integrate with the neurotransmitter release machinery by establishing interactions with local molecules [98,99]. Upon depolarization, calcium influx via $\mathrm{Ca}_{\mathrm{V}} 2.1$ and $\mathrm{Ca}_{\mathrm{V}} 2.2$ triggers the fusion of presynaptic vesicles with the membrane and, consequently, allows neurotransmitter release $[98,100]$. The relative content of $\mathrm{Ca}_{\mathrm{V}} 2.1$ and $\mathrm{Ca}_{\mathrm{V}} 2.2$ at the synapses may vary according to neuronal type [101]. For example, the synapses of the spinal dorsal horn express $\mathrm{Ca}_{\mathrm{V}} 2.2$ exclusively, whereas $\mathrm{Ca}_{\mathrm{V}} 2.1$ channels are also located in the soma of glutamatergic neurons. Here, $\mathrm{Ca}_{\mathrm{V}} 2.1$ mediates excitation-transcription coupling and has been associated with the ability to control the expression of the synaptic syntaxin1A $[87,102]$. Gain-of-function mutations of $\mathrm{Ca}_{V} 2.1$ cause familial hemiplegic migraine and impair synapse formation in animal models [49,103].

$\mathrm{Ca}_{\mathrm{V}} 3$ channels are expressed throughout the nervous system and are involved in cerebellar, thalamic, and cortical functions [104]. These channels are involved in the tuning of neuronal excitability and participate in the processing of pain, sleep, motor functions, and the release of neurotransmitters and hormones [11]. The three $\mathrm{Ca}_{\mathrm{V}} 3$ isoforms confer distinct firing patterns to neurons. A further level of regulation complexity is achieved by channel-alternative splicing $[105,106]$. A comprehensive recent review comprises the latest clinical findings on $\mathrm{Ca}_{\mathrm{V}} 3$ channelopathies and their underlying cellular mechanisms [11].

\section{L-type VGCCs in Psychiatric Disorders}

Genome-wide association studies identified an intronic single-nucleotide polymorphism, rs1006737, of the CACNA1C encoding the Cav1.2 channel as a risk factor for bipolar 
disorders [31,32], unipolar major depressive disorder [32-34], schizophrenia [33,35-39] and post-traumatic stress syndrome $[40,41]$. Individuals carrying the CACNA1C rs 1006737 present altered neuronal circuitry in fMRI analysis, corroborating the central role of these channels in information processing in the brain [107]. In healthy humans, the CACNA1C rs1006737 is associated with decreased attention, working memory, and verbal fluency [38,107-109]. In line with these findings, the DHP isradipine was shown to improve verbal memory and attention in patients affected by schizophrenia in a recent randomized controlled trial [110]. How non-coding intronic single nucleotide polymorphisms can cause a pathological condition is unclear, but it is thought to happen by altering the expression level of $\mathrm{Ca}_{\mathrm{V}} 1.2$ and most likely the pattern of channel splice variants in the brain [111]. Recently, numerous splice variants of the human neuronal $\mathrm{Ca}_{\mathrm{V}} 1.2$ have been identified, and their sequences are available in an accessible repository [111]. Further research is needed to attribute specific functions to these splice variants in neurons. From a pharmacological point of view, alternative splicing may vary the sensitivity of L-type channels to DHP [112].

The CACNA1D gene encoding the $\mathrm{Ca}_{\mathrm{V}} 1.3$ has been identified as a risk gene for bipolar disorder $[45,46]$. In a pilot study on a very limited number of individuals with bipolar disorder, isradipine administration ameliorated the symptoms of comorbid depression [113]. Although it was too limited to draw valid conclusions, this study suggested a possible therapeutic application of L-type VGCCs antagonists in bipolar disorders. Therefore, this topic deserves further investigation. In this regard, a clinical trial (ClinicalTrials.gov identifier: NCT01784666) was approved but, unfortunately, it was prematurely terminated because of an insufficient enrollment of eligible patients.

Timothy syndrome (TS) is a multisystem disorder characterized by congenital heart disease, immunodeficiency, intermittent hypoglycemia, cognitive impairment, and autism [7,25]. This condition is associated with the mutually exclusive alternative splicing of the exons 8 and $8 \mathrm{a}$ of the $\mathrm{Ca}_{\mathrm{V}}$ 1.2. In one form of TS, the pathogenic G406R mutation is located within the exon 8a. In a second form of TS, Cav 1.2 exhibits the G406R or a G402R mutation within the alternative spliced exon 8 . Both forms of TS present autism, but the most pronounced traits are displayed in the TS associated with exon 8 , as this splice variant is more expressed in the brain than the $8 \mathrm{a}[8,25]$. The G406R substitution is a gain-of-function mutation and reduces voltage-dependent channel inactivation [26]. Interestingly, iPSC-derived neurons from individuals with TS showed an excessive expression of the tyrosine hydroxylase (TH) gene. Treatment with roscovitine-which increases channel inactivation $[27,28]$ and, therefore, can rescue the inactivation impairment displayed by the G406R Cav1.2 mutantstrongly reduced the redundant production of $\mathrm{TH}$, restoring the physiological expression levels of this gene [88]. This finding is consistent with other studies in which roscovitine reduced the prolongation of the action potential in iPSC-derived cardiomyocytes from individuals with TS, reestablishing proper membrane excitability $[29,114]$. Interestingly, treatment with nifedipine did not retrieve adequate levels of $T H$ production in TS-derived iPSCs neurons [29]. This result suggests that restoring the amplitude of calcium currents may not suffice to fully rescue an integrative physiological mechanism. Instead, restoring physiological channel kinetics is necessary. Consistently, the signaling mode of $\mathrm{Ca}_{\mathrm{V}} 1.2$ was previously reported to be either voltage- or calcium-dependent, suggesting the existence of multiple mechanisms by which the same channel can selectively control diverse cellular processes [115]. These data indicate that the tailored rational design of new molecules able to selectively target different gating modes can be fundamental to correcting the abnormal signaling pathways that are determined by channel mutations.

Several gain-of-function de novo missense mutations of $\mathrm{Ca}_{\mathrm{V}} 1.3$ are causative of the pathological conditions associated with intellectual disabilities, autism spectrum disorders, developmental delays, and hypotonia, as well as hyperinsulinemic hypoglycemia and/or congenital aldosteronism [44]. Interestingly, among all the described mutations, the germline $\mathrm{Ca}_{\mathrm{V}}$ 1.3-S652L substitution shows increased sensitivity to isradipine [116], suggesting that the DHP-hypersensitivity of this channel mutant may be exploited for clinical practice. Therefore, further investigations in this direction are worthwhile. A recent 
review discusses in depth the $\mathrm{Ca}_{\mathrm{V}} 1.3$ gain-of-function mutations linked to autism and comorbidities, the underlying molecular mechanisms, clinical implications, and therapeutic potential of channel blockers [44]. Autism is also associated with single-nucleotide polymorphism in $\mathrm{Ca}_{\mathrm{V}} 3$ channel isoforms $[117,118]$. Furthermore, several missense mutations of the Cav3.2 channel were identified in 6 out of 461 individuals with autism spectrum disorders. These mutations are located within channel domains that are highly conserved across species and were found to strongly reduce $\mathrm{Ca}_{\mathrm{V}} 3.2$ channel activity [73]. Such a loss of function may cause functional and structural alterations to the brain circuitry, leading to the development of autism [73]. A possible pharmacological treatment may include either promoting channel trafficking to the membrane or the administration of drugs able to increase $\mathrm{Ca}_{\mathrm{V}} 3.2$ activity.

Gabapentin and pregabalin (gabapentinoids) are effective in treating anxiety disorders in humans [119]. Because gabapentinoids target $\mathrm{Ca}_{V} \alpha_{2} \delta$ subunits, the anxiolytic efficacy of these compounds is consistent with the finding that $\mathrm{Ca}_{\mathrm{V}} \alpha_{2} \delta 1$ level increased in a rat model in which anxiety was chemically induced [119]. Anxiety intimately connects with fear, and the underlying neural circuitries are tied [120]. In fear-conditioned rats, the expression of $\mathrm{Ca}_{\mathrm{V}} 1.2$ and $\mathrm{Ca}_{\mathrm{V}} 1.3$ was found to be upregulated, and the administration of nimodipine blocked the startle response in these rodents [121]. These results suggest that DHP could be used as an anxiolytic. Nevertheless, some discrepancy is found in additional studies. $\mathrm{Ca}_{\mathrm{V}} 1.2$ haploinsufficiency or its deletion in the forebrain were shown to induce an anxiety phenotype in mice [122]. Consistently, higher doses of nifedipine and verapamil exerted an anxiogenic effect in rodents [8,123]. Direct evidence that $\mathrm{Ca}_{\mathrm{V}} 1.3$ suppression may have an anxiolytic effect is weak $[8,123]$. Therefore, the role of $\mathrm{Ca}_{\mathrm{V}} 1.2$ in anxiety must be clarified to ponder the therapeutic potential of selective L-type channel blockers. Finally, Cav2.2 knock-out mice show lower anxiety levels than wild-type mice, suggesting that inhibitors of Cav2.2 might be potential anxiolytic drugs [124].

\section{VGCC Inhibitors in the Treatment of Parkinson's Disease}

Parkinson's disease (PD) is a common neurodegenerative disorder, the incidence of which is progressively increasing. PD is characterized by a loss of dopaminergic neurons in the substantia nigra pars compacta and in the striatum. This neurodegeneration leads to a progressive impairment in motor skills, tremors, and development of psychosis [125,126]. The mainstay pharmacological treatment that is currently available targets the motor symptoms and includes several drugs as anticholinergic agents, beta-blockers, and dopamine receptor agonists [127]. Unfortunately, the etiology of loss in dopaminergic neurons is still unclear and this gap of knowledge strongly hampers tailored therapeutic interventions to avoid neurodegeneration. Research efforts provide an emerging frame comprising a network of contributing causes, including specific genes, environmental risk factors, and cellular metabolism stressors [128]. Multiple genes are involved in the development of PD, including $\alpha$-synuclein, Parkin, PTEN-induced putative kinase 1 (PINK1), and leucine-rich repeat serine/threonine protein kinase 2 (LRRK2) [129]. Within the PD condition, these genes are often associated with mitochondrial dysfunction and calcium homeostasis dysregulation [130]. Interestingly, several epidemiological studies reported that the incidence of PD was reduced by $30 \%$ in patients treated with DHP for hypertension [131-133]. This observation suggested that L-type VGCCs are involved in the pathogenesis and/or progression of this neurological disorder and that DHP could be used to prevent the loss of neurons by inhibiting the L-type calcium channels. In line with this hypothesis, several other findings suggest that the upregulation of L-type Cav1.3 may be critical in neuronal loss from PD [134]. In the substantia nigra dopamine neurons, Cav1.3 contributes to pacemaker activity, which is sensitive to DHP $[135,136]$. Ca 1.3 pacemaker activity was shown to be linked to mitochondrial-dependent oxidative stress, which is typical of PD [137]. Furthermore, the $\mathrm{Ca}_{\mathrm{V}} 1.3 / \mathrm{Ca}_{\mathrm{V}} 1.2$ expression ratio increases in favor of the $\mathrm{Ca}_{\mathrm{V}} 1.3$ in PD brains [138]. Altogether, these results indicate that selective inhibitors of $\mathrm{Ca}_{\mathrm{V}} 1.3$ channels could be a potential strategy for treating PD. However, selective Cav1.3 inhibitors are 
not available in clinical practice, and the only possibility to test this hypothesis was to use one of the existing DHP. The main pitfall of DHP is the blockade of both Cav1.2 and $\mathrm{Ca}_{\mathrm{V}} 1.3$ [139]. Hence, the selective pharmacological targeting of Cav1.3 is not possible as both isoforms are concomitantly expressed in neurons. To complicate the issue, DHPs show a higher affinity for $\mathrm{Ca}_{\mathrm{V}} 1.2$ than $\mathrm{Ca}_{\mathrm{V}} 1.3$ [134,140]. Among DHPs, isradipine shows a high affinity for $\mathrm{Ca}_{\mathrm{V}} 1.3$, although preferential selectivity for $\mathrm{Ca}_{\mathrm{V}} 1.2$ persists [141]. Therefore, isradipine has been the DHP candidate of choice for the clinical trials on PD.

A Phase-II clinical trial demonstrated that $10 \mathrm{mg}$ /day is the maximal daily dosage of isradipine tolerated by early PD patients who do not yet require dopaminergic therapy [142]. Considering its short half-life, isradipine was administrated twice a day, $5 \mathrm{mg}$ for each dose. The most common side effects were peripheral edema and dizziness [142]. This therapeutic regime was then used for a thirty-six-month randomized Phase-III trial, to test the efficacy of isradipine in delaying the clinical progression of PD in early-diagnosed patients [143]. Participants were tested on their ability to score using the unified Parkinson's disease rating scale (UPDRS) - including cognitive functions, daily living activities, and motor function, which are all sensitive to anti-Parkinson's medications-the time to onset of severe motor complications and the initiation of standard anti-Parkinson's therapy. Despite the researchers' high hopes, treatment with isradipine failed to score positively against the placebo for all these endpoints. Thus, the results of the clinical trial did not support the hypothesis that isradipine, at this dosage, can slow the progression of PD [143]. One possible explanation for this result is that the bioavailability of isradipine at the used dosage was not sufficient to target the $\mathrm{Ca}_{\mathrm{V}} 1.3$ channels in neurons, but a direct empiric measure of effective local drug engagement is not feasible [143,144]. This explanation has been further supported by modeling the pharmacokinetics of isradipine based on the trial data, indicating that the critical threshold for therapeutic efficacy might have been reached only transiently and for a short time [144]. The administration of higher doses is discouraged because of the secondary cardiovascular effects that isradipine may induce. The most effective strategy by which to test the therapeutic efficacy of blocking $\mathrm{Ca}_{\mathrm{V}} 1.3$ in PD would be the identification of $\mathrm{Ca}_{\mathrm{V}} 1.3$-selective inhibitors. Ideally, such inhibitors should be able to target the $\mathrm{Ca}_{\mathrm{V}} 1.3$ channels in neurons and not in the other tissues where they are expressed, such as the cardiac sinoatrial node, endocrine system, and the cochlea.

Finally, R- and T-type VGCCs are emerging as possible therapeutic targets for PD [8]. For example, the compound NNC 55-0396 was shown to offset locomotor deficits in a rodent model of PD by inhibiting the T-type channels [145]. Furthermore, the activity of T-type VGCCs was recently found to mediate the dysregulation of calcium homeostasis in PARK6 patient-specific-induced pluripotent stem cells [146]. Therefore, the inhibitors of Ttype channels could represent a valid strategy in PD treatment $[147,148]$. Recent advances and biomedical findings support this possibility and are extensively discussed in a recent review [149].

\section{The Potential of Pyrimidine-2,4,6-Triones (PYT) as Cav1.3 Selective Inhibitors}

The clinical need for selective Cav1.3 blockers does not apply only to PD. Indeed, gain-of-function mutations of $\mathrm{Ca}_{\mathrm{V}} 1.3$ are associated with autism and epilepsy $[116,150]$. In the ventral tegmental area, $\mathrm{Ca}_{\mathrm{V}} 1.3$ is involved in cocaine addiction and related comorbid mood disorders [151]. In addition, genetic data identify CACNA1D as being a risk factor for bipolar disorders $[45,46]$. The L-VGCCs inhibitors used in clinical practice, such as isradipine, verapamil, and diltiazem, show a higher affinity for $\mathrm{Ca}_{\mathrm{V}} 1.2$ rather than $\mathrm{Ca}_{\mathrm{V}} 1.3$ channels $[140,141]$. Consequently, we can expect that the significant inhibition of Cav1.3 in the brain would require the administration of high doses of calcium channel antagonists, leading to cardiovascular side effects induced by the blockade of $\mathrm{Ca}_{\mathrm{V}} 1.2$. Therefore, the effective inhibition of $\mathrm{Ca}_{\mathrm{V}} 1.3$ in the central nervous system requires selective molecules sparing $\mathrm{Ca}_{\mathrm{V}}$ 1.2. The interest of the scientific community is high, and several laboratories are currently testing innovative compounds targeting $\mathrm{Ca}_{V} 1.3$. These compounds could be of great interest for both basic science and therapeutics. A novel class of small molecules, 
pyrimidine-2,4,6-triones (PYT), has been indicated as a potential molecular paradigm for generating possible Cav1.3-selective inhibitors. In particular, 1-(3-chlorophenethyl)-3cyclopentylpyrimidine-2,4,6-(1H,3H,5H)-trione) (also known as Compound 8 (or PYT06 in [152])) was shown to be highly selective for $\mathrm{Ca}_{\mathrm{V}} 1.3\left(\mathrm{IC}_{50}=24.3 \pm 0.7 \mu \mathrm{M}\right)$ over $\mathrm{Ca}_{\mathrm{V}} 1.2$ $(1162 \mu \mathrm{M})$ [153]. The structural bases for its selectivity to Cav1.3 and voltage-dependent inhibition mechanism of channel gating were recently identified [154]. Compound 8 binds to the $\mathrm{Ca}_{\mathrm{V}} 1.3 \alpha_{1}$ subunit in the DHP-binding pocket in a voltage-dependent way, which confers negative allosteric modulation [154]. However, electrophysiology recordings in HEK-293 cells expressing various combinations of $\mathrm{Ca}_{\mathrm{V}} 1.3$ or $\mathrm{Ca}_{\mathrm{V}} 1.2 \alpha_{1}$ splice variants with different $\mathrm{Ca}_{\mathrm{V}} \beta$ isoforms show that the selectivity of Compound 8 for $\mathrm{Ca}_{\mathrm{V}} 1.3$ is modest and is highly dependent on the molecular identity of the channel complex [155]. Intriguingly, Ortner et al. (2014) [156] showed that under their experimental conditions, Compound 8, rather than reducing L-type currents, increased calcium influx through $\mathrm{Ca}_{\mathrm{V}} 1.3$ and $\mathrm{Ca}_{V} 1.2$ by slowing current activation and inactivation, as well as enhancing tail currents in HEK-293 cells expressing the channel subunits and in chromaffin cells. In the same study, the weak inhibition of L-type currents occurred only when using $\mathrm{Ba}^{2+}$ as a charge carrier, but no selective action on $\mathrm{Ca}_{V} 1.3$ over $\mathrm{Ca}_{V} 1.2$ was observed [156]. These discrepancies were in part explained by the presence of a critical mutation in the DHP-binding pocket-the interaction site of Compound 8-of the Cav $1.3 \alpha_{1}$ subunit used by Ortner et al. (2014), which could impede the proper interaction of Compound 8 with the channel pore $[154,156]$. The enhancement of tail currents could be interpreted as the effect of a secondary binding site on the channel, which became evident in the absence of a higher-affinity binding on the DHP pocket $[154,156]$. However, the mutated DHP-binding site could not explain the agonist action of Compound 8 on native L-type currents in chromaffin cells, as reported by Ortner et al. [156]. Nonetheless, the inhibitory function of Compound 8 on L-Type currents was observed in neurons in another study [157]. While the mechanisms underlying the action of Compound 8 on L-type channels are controversial, these studies indicate that the cellular environment, subunit splice variants forming the channel complex, and the neuronal firing mode affect the action of Compound 8 on L-VGCCs. Further characterization in native cells expressing $\mathrm{Ca}_{V} 1.3$ - for example, different types of neurons, sinoatrial node myocytes, pancreatic beta cells, and chromaffin cells-will be necessary to understand the mechanism of action of Compound 8. The outcome of these investigations could provide important information on the tissue-specific effects of this molecule. These findings will be useful to develop pharmacological treatments for $C A C N A 1 D$-dependent neuropsychiatric disorders and for the evaluation of potential side effects.

\section{VGCCs Inhibitors in Pain Treatment}

Pain stimuli are detected by peripheral nociceptors innervating the skin and organ tissues [9]. Then, action potentials propagate along the primary afferent fibers to the synapses in the spinal dorsal horn, where the excitatory synaptic transmission connects to those brain centers coding pain [8,158]. In dorsal horn neurons, Cav3.2 VGCCs participate in nociceptive pathways by regulating membrane excitability, and, to a lesser extent, synaptic transmission. Conversely, $\mathrm{Ca}_{\mathrm{V}} 2.2$ is the main regulator of synaptic transmission [8,51]. $\mathrm{Ca}_{V} 2.2$ and Cav3.2 are upregulated in conditions of chronic pain [52-54], while their inhibition mediates analgesia in mice [51]. The inhibition of $\mathrm{Ca}_{\mathrm{V}} 2.2$ constitutes a prime pharmacological strategy to implement efficient pain therapy. Cav2.2 are known to form complexes with $\mu$-opioid receptors. The administration of the $\mu$-opioid receptor agonist morphine inhibits $\mathrm{Ca}_{\mathrm{V}} 2.2$, reduces neurotransmitter release from primary afferent neurons, and exerts a powerful analgesic function $[55,56]$. The expression of the $\mathrm{Ca}_{\mathrm{V}} 2.2$ variant containing the exon 37a plays a central role in pain signaling $[57,58]$. Interestingly, an alternative splicing of $\mathrm{Ca}_{\mathrm{V}} 2.2$ at exons $37 \mathrm{a}$ and $37 \mathrm{~b}$ diminishes the efficacy of morphine, probably by altering the composition of the $\mathrm{Ca}_{\mathrm{V}} 2.2$ complex with $\mu$-opioid receptors, preventing channel regulation by morphine [55]. The same study showed that the analgesic efficacy of gabapentin and Ziconotide is not affected by $\mathrm{Cav}_{\mathrm{V}} 2.2$ alternative splicing [55]. 
Such difference is attributable to the different mechanisms of action of these drugs with respect to morphine. Ziconotide acts by occluding the channel pore, whereas gabapentin targets the $\mathrm{Ca}_{V} \alpha_{2} \delta$ subunits, inducing channel pore $\alpha_{1}$ internalization $[55,59]$. The $\mathrm{Ca}_{V} \alpha_{2} \delta$ subunits are upregulated in chronic pain states, determining an increase of $\mathrm{Ca}_{\mathrm{V}} 2.2$ trafficking and localization at synapses [60,61]. Gabapentinoids reduce the expression levels of $\mathrm{Ca}_{\mathrm{V}} 2.2$ at the presynaptic membrane by binding to $\mathrm{Ca}_{\mathrm{V}} \alpha_{2} \delta$. This hampers synaptic transmission, thereby reducing the efficacy of nociceptive signaling [159]. Ziconotide is delivered intrathecally to treat pain in cancer patients. It has several disadvantages, including its mode of administration - which depends on a minipump implant-and numerous and severe side effects [160-163]. These side effects are possibly due to the lack of state-dependence of the Ziconotide blockade of calcium channels. Indeed, Ziconotide would block channels irrespective of the basal or hyperactive firing of neurons, whereas a state-dependent inhibitor would preferentially target the channels in hyperactive neurons. Along the same lines, several use-dependent small molecules inhibiting Cav2.2 that are also capable of analgesic activity on animal models were developed over the years. Some of these molecules, such as TROX-1, Z160 (also named NMED-160 or NP-118809), and CNV2197944 entered clinical trials [8,164,165].

Small molecules isolated from the rhizome and roots of Valeriana jatamansi Jones (Caprifoliaceae), an annual herb mainly found in China and India [166], show significant inhibition of $\mathrm{Ca}_{V} 2.2$ and $\mathrm{Ca}_{V} 3.1$ channels. These molecules exhibit selectivity for $\mathrm{Ca}_{\mathrm{V}} 2.2$ and $\mathrm{Ca}_{\mathrm{V}} 3.1$ against $\mathrm{Ca}_{\mathrm{V}} 1.2, \mathrm{Ca}_{\mathrm{V}} 2.1$, and $\mathrm{KCNH} 2$ [167]. Together with other blockers of $\mathrm{Ca}_{V} 2.2$ endowed with analgesic properties in animal models [168,169], these molecules may represent an attractive option for exploring novel possibilities for treatment in pain therapy targeting VGCCs. Another possibility could be interfering with $\mathrm{Ca}_{\mathrm{V}} 2.2$ trafficking to the membrane so that the presynaptic amount of calcium channels would be reduced, and the transmission of nociceptive stimuli would be inhibited. A recent example of this strategy exploits hot-spots at the interface of $\mathrm{Ca}_{V} \alpha_{1}-\mathrm{Ca}_{\mathrm{V}} \beta$ interaction, constituted by three critical amino acids: Tyr-437, Trp-440, and Ile-441 on the $\mathrm{Ca}_{V} \alpha_{1}$ pore-forming subunit $[170,171]$. By the structure-based screening of commercial libraries, the BTT-3 small molecule was selected and used as a molecular paradigm to develop BTT-266 and BTT-369-compound 6 and 14 in [170], respectively-which reduced $\mathrm{Ca}_{\mathrm{V}} 2.2$ trafficking to the membrane and modulated channel voltage-dependence activation and steady-state inactivation [170]. In mice, these compounds relieve pain with different duration and efficacy. The use of these molecules may pave the way to treating other channelopathies with aberrant $\alpha_{1}$ trafficking and biophysical properties [170]. Similarly, small molecules mimicking the interaction of STAC3 with Cav1.1 could offset the abnormal muscle physiology of Native American myopathy $[172,173]$.

\section{VGCCs in Seizure Disorders}

Seizures originate from membrane hyperexcitability and/or the abnormal synchronization of neurons in the brain, which perturbs the physiological pattern of neuronal circuitry $[8,174]$. Proper connections between neural circuits permit the coordination of different tasks and behaviors. Thus, the disruption of normal interconnectivity may account for epilepsy comorbidities, such as depression, learning disabilities, and autistic features [174]. Within the epileptic focus, seizures are believed to derive from increased excitation or decreased inhibition and can be determined by a brain tumor or damage to brain structures $[8,174,175]$. Conversely, idiopathic seizures are triggered by systemic conditions, such as fever or hypoxia. Genetic conditions of ion channels and GABA receptors are also involved in seizures [147,176-178]. In the past two decades, important advances in our understanding of the physiopathological mechanisms underpinning seizures have led to an increase in the available antiepileptic drugs. Nevertheless, about one-third of patients are refractory to validated pharmacological and medical treatments, while others suffer severe side effects $[174,179-183]$. Therefore, there exists an urgent need to develop 
novel treatments that are able to contain the extent and frequency of seizure episodes in drug-resistant patients and to minimize the adverse effects $[174,179,184]$.

Several lines of evidence show that T-type VGCCs are involved in absence seizures. The expression level of $\mathrm{Ca}_{\mathrm{V}} 3.2$ mRNA and T-type currents increase in the reticular nucleus of the thalamus in absence epilepsy rats from Strasbourg (GAERS), a model of absence epilepsy [67]. Increased thalamic T-type currents are attributable to a gain-of-function mutation in exon 24 of $\mathrm{Ca}_{V} 3.2$, identified in GAERS. Interestingly, the gain-of-function phenotype depends on the alternative splicing of $\mathrm{Ca}_{\mathrm{v}} 3.2$ exon 25 [68]. Furthermore, mutations within the CACNA1H gene encoding $\mathrm{Ca}_{\mathrm{V}} 3.2$ have been associated with several forms of epilepsy [69]. These mutations generate gain-of-function channels or enhance channel trafficking to the neuronal membrane, thereby increasing the amount of functional surface that expressed $\mathrm{Ca}_{V} 3.2$ [70-72]. Mice overexpressing Cav3.1 channels show increased thalamocortical activity and absence seizures [66]. Recently, gain-of-function Cav3.3 channel mutants, identified in patients with seizures and neurodevelopmental disorders, were shown to cause hyperexcitability when expressed in chromaffin cells; this finding could explain seizures in patients [74]. Overall, these data indicate that enhanced T-type currents in the thalamus predispose a sensitivity to absence seizures. Therefore, the inhibition of $\mathrm{Ca}_{\mathrm{V}} 3$ channels represents a valid strategy for the pharmacological treatment of seizures.

The T-type VGCCs blocker ethosuximide is used in the treatment of absence seizures [185]. This small molecule exerts its action on all $\mathrm{Ca}_{\mathrm{V}} 3$ isoforms and binds with a higher affinity to inactivated channels [186]. However, ethosuximide is rather unspecific as it was also shown to inhibit voltage-gated sodium channels and calcium-activated potassium channels in the thalamic and cortical neurons $[187,188]$. Moreover, ethosuximide administration increases GABA levels and decreases glutamate in GEARS [189]. Among the anti-epileptic drugs, sodium valproate can inhibit T-type currents in addition to sodium channels [190]. Zonisamide is used to control seizures and was also shown to inhibit T-type VGCCs. In addition, Zonisamide relieved pain responses in rodents, corroborating the role of these channels in the nociceptive pathways [191,192]. The experimental evidence for the involvement of T-type VGCCs in seizures prompted the development of a novel molecule based on the rational design of NP118809 (or Z160), a high-affinity N-type channel blocker able to control pain in animal models of inflammatory and neuropathic pain $[164,193]$. This approach led to Z944, a high-affinity pan-T-type blocker, exhibiting state- and frequencydependent effects and that was able to reduce seizures by $85-90 \%$ in GAERS [193].

Gabapentin and pregabalin are used in clinical practice to treat focal and partial seizures [194]. Because these drugs bind to the $\mathrm{Ca}_{V} \alpha_{2} \delta$ subunit, they induce several unwanted effects by targeting multiple VGCCs, irrespective of the $\mathrm{Ca}_{V} \alpha_{1}$ isoform. Furthermore, in patients treated for neuropathic pain with drugs targeting VGCCs, such as benzodiazepines and opioids, the use of gabapentinoids is critical because of possible pharmacodynamic interactions [194].

The antiepileptics lamotrigine and topiramate target multiple channels and receptors, and both were shown to inhibit Cav2.3 channels, among others [62,63]. Indeed, in rodents, the anti-seizure effect of lamotrigine is critically dependent on the expression of $\mathrm{Ca}_{\mathrm{V}} 2.3$, and it is lost in Cav2.3-null mice [64]. Topiramate blocks Cav2.3 in a state-dependent manner, meaning that mainly hyperactive neurons are targeted [65].

L-type $\mathrm{Ca}_{\mathrm{V}} 1.2$ channels were proposed to be involved in the onset of febrile seizures [195]. Indeed, the activation of $\mathrm{Ca}_{\mathrm{V}} 1.2$ in pyramidal neurons is shifted to hyperpolarized potentials at a temperature of about $40{ }^{\circ} \mathrm{C}$, allowing these channels to support intrinsic firing properties and, therefore, likely supporting febrile seizures [195]. Consistently, nimodipine prevented the development of temperature-induced seizures in rodents, indicating that L-type channel blockers could be explored as a pharmacological tool to treat febrile seizures [195]. However, it is well known that nimodipine also slightly blocks T-type channels [196]. Therefore, the relative contributions of L-type and T-type channels in febrile seizure and in the protecting effect of nimodipine need to be clarified. 


\section{VGCCs in Migraine}

Familial hemiplegic migraine 1 is caused by the S218L mutation of $\mathrm{Ca}_{\mathrm{V}} 2.1$, which alters the kinetic properties of the channel currents and hampers proper synaptic formation and synaptic plasticity [49,50]. A small molecule termed 2,5'-di(tertbutyl)-1,4,benzohydroquinone (BHQ) - primarily known as the SERCA inhibitor-confers a dual effect on $\mathrm{CaV}_{\mathrm{V}} 2.1$ channels by inhibiting voltage-dependent activation and enhancing calciumdependent facilitation [49]. The use of the BHQ on the Ca $2.1-S 218 \mathrm{~L}$ mutant rescues normal current properties and restores proper synaptic physiology in Drosophila and animal models [49]. These results show that reestablishing normal channel kinetics rescues the disease phenotype and indicates a strategy by which to treat familial hemiplegic migraines in humans.

\section{VGCCs in the Aging Brain}

VGCCs undergo age- and gender-dependent alternative splicing, suggesting that different ratios of precise splice variants may support changes in the aging brain [197]. Age-dependent forms of mid-channel proteolysis, with the generation of Cav1.2 with diverse biophysical properties, were reported [198]. Mid-channel proteolysis may serve as a homeostatic control of VGCCs activity. This hypothesis is supported by the finding that proteolysis can be reduced by inhibiting L-VGCCs with the DHP nifedipine in cultured neurons and slices [198]. In aging mice, neuronal Cav1.2 exhibited higher levels of phosphorylation on serine 1928, which increases open-channel probability $[199,200]$. $\mathrm{Ca}_{\mathrm{V}} 1.2$ phosphorylation may also be involved in the regulation of channel trafficking in the hippocampal neurons [201]. Thus, knowing the age-dependent regulation of VGCCs might offer therapeutic strategies to compensate for the consequences of changes in neuronal calcium homeostasis that are typical of later life.

\section{Summary}

VGCCs are involved in several neurological and psychiatric conditions. However, the palette of molecules targeting these channels is limited, applying only to some channel subtypes, and is restricted to an inhibitory function. There exists the need to identify novel specific modulators and inhibitors that could be considered for use in clinical practice. The topics discussed in the previous paragraphs highlight two main points. First, compounds in use for some disease may be considered also for other conditions (Table 2). Second, several issues could be exploited in evaluating new small molecules toward VGCC-dependent pathologies. These aspects include an understanding of the tissue- and function-specific channel biophysical properties, splice variant expression patterns, and the molecular composition of signaling complexes and transduction cascades. Based on these notions, the researcher can direct drug development toward the most effective strategies.

Table 2. The applications of selected VGCC blockers and modulators in neurological and psychiatric conditions.

\begin{tabular}{|c|c|c|c|}
\hline Small Molecules & Approved Applications & Target & Potential Applications \# \\
\hline Isradipine & Hypertension & L-type channels & $\begin{array}{l}\text { Autism [44,116], failed Phase-III trial for } \\
\text { PD [116], dependency [151] }\end{array}$ \\
\hline Nimpodipine & Hypertension & L-type channels & Anxiety [121], febrile seizures [195] \\
\hline Roscovitine & NA & $\mathrm{Ca}_{\mathrm{V}} 1.2$, L-type currents & Timothy syndrome $[29,114]$ \\
\hline Pregabalin & Pain and seizures & $\mathrm{Ca}_{V} \alpha_{2} \delta$ & Anxiety [119] \\
\hline Gabapentin & Pain and seizures & $\mathrm{Ca}_{V} \alpha_{2} \delta$ & Anxiety [119] \\
\hline
\end{tabular}


Table 2. Cont.

\begin{tabular}{|c|c|c|c|}
\hline Small Molecules & Approved Applications & Target & Potential Applications \# \\
\hline NNC 55-0396 & NA & T-type currents & PD [145] \\
\hline $\begin{array}{c}\text { Valeriana jatamansi } \\
\text { derived small molecules }\end{array}$ & NA & $\mathrm{Ca}_{V} 2.2, \mathrm{Ca}_{V} 3.1$ & Pain [167] \\
\hline Ziconotide & Pain & $\mathrm{Ca}_{V} 2.2$ & NA \\
\hline BTT-266, BTT-369 & NA & $\beta$ binding domain on $\alpha_{1}$ & Pain [170] \\
\hline Ethosuximide & Seizures & T-type channels & Pain [185] \\
\hline Valproate & Seizures & T-type channels & PD $[190,191]$ \\
\hline Zonisamide & Seizures & T-type channels & Pain and PD $[191,192]$ \\
\hline NP118809 (or Z160) & NA & N-type channels & Pain $[164,193]$ \\
\hline Z944 & NA & T-type channels & Seizures, pain [193] \\
\hline Lamotrigine & Seizures & R-type channels & Pain [62] \\
\hline Benzohydroquinone & NA & $\mathrm{Ca}_{\mathrm{V}} 2.1$ & Familial hemiplegic migraine 1 [49] \\
\hline
\end{tabular}

NA, not applicable; " potential applications are given on the basis of preclinical findings.

Current research is progressively integrating those findings provided by genetic screenings with the molecular and cellular mechanisms downstream of calcium channels that are involved in diseases. Together with structural data on channel complexes, these notions are crucial for screening existing small molecule libraries or planning the rational design of substances already in use. Ameliorating the clinical course of VGCC-dependent diseases still requires considerable transdisciplinary research efforts.

Author Contributions: S.L. and V.D.B. wrote the manuscript. All authors have read and agreed to the published version of the manuscript.

Funding: This work was supported by the Austrian Funding Agency FWF P 33225 to V.D.B.

Data Availability Statement: Not applicable.

Acknowledgments: We thank M. E. Mangoni, Institute of Functional Genomics (IGF), University of Montpellier, for critical reading of the manuscript. Open Access Funding by the Austrian Science Fund (FWF).

Conflicts of Interest: The authors declare no conflict of interest.

\section{References}

1. Kim, J.B. Channelopathies. Korean J. Pediatr. 2014, 57, 1-18. [CrossRef] [PubMed]

2. Santos, R.; Ursu, O.; Gaulton, A.; Bento, A.P.; Donadi, R.S.; Bologa, C.G.; Karlsson, A.; Al-Lazikani, B.; Hersey, A.; Oprea, T.I.; et al. A comprehensive map of molecular drug targets. Nat. Rev. Drug Discov. 2017, 16, 19-34. [CrossRef]

3. Zamponi, G.W.; Striessnig, J.; Koschak, A.; Dolphin, A.C. The Physiology, Pathology, and Pharmacology of Voltage-Gated Calcium Channels and Their Future Therapeutic Potential. Pharmacol. Rev. 2015, 67, 821-870. [CrossRef] [PubMed]

4. Heyes, S.; Pratt, W.S.; Rees, E.; Dahimene, S.; Ferron, L.; Owen, M.J.; Dolphin, A.C. Genetic disruption of voltage-gated calcium channels in psychiatric and neurological disorders. Prog. Neurobiol. 2015, 134, 36-54. [CrossRef]

5. Flucher, B.E. Skeletal muscle CaV1.1 channelopathies. Pflugers Arch. 2020, 472, 739-754. [CrossRef] [PubMed]

6. Ablinger, C.; Geisler, S.M.; Stanika, R.I.; Klein, C.T.; Obermair, G.J. Neuronal alpha2delta proteins and brain disorders. Pflugers Arch. 2020, 472, 845-863. [CrossRef] [PubMed]

7. Marcantoni, A.; Calorio, C.; Hidisoglu, E.; Chiantia, G.; Carbone, E. Cav1.2 channelopathies causing autism: New hallmarks on Timothy syndrome. Pflugers Arch. 2020, 472, 775-789. [CrossRef] [PubMed]

8. Zamponi, G.W. Targeting voltage-gated calcium channels in neurological and psychiatric diseases. Nat. Rev. Drug Discov. 2016, 15, 19-34. [CrossRef]

9. Striessnig, J. Voltage-Gated $\mathrm{Ca}(2+)$-Channel alpha1-Subunit de novo Missense Mutations: Gain or Loss of Function-Implications for Potential Therapies. Front. Synaptic Neurosci. 2021, 13, 634760. [CrossRef] [PubMed]

10. Kabir, Z.D.; Martinez-Rivera, A.; Rajadhyaksha, A.M. From Gene to Behavior: L-Type Calcium Channel Mechanisms Underlying Neuropsychiatric Symptoms. Neurotherapeutics 2017, 14, 588-613. [CrossRef] [PubMed] 
11. Lory, P.; Nicole, S.; Monteil, A. Neuronal Cav3 channelopathies: Recent progress and perspectives. Pflugers Arch. 2020, 472, 831-844. [CrossRef] [PubMed]

12. Weiss, N.; Zamponi, G.W. Genetic T-type calcium channelopathies. J. Med. Genet. 2020, 57, 1-10. [CrossRef] [PubMed]

13. Catterall, W.A. Voltage-gated calcium channels. Cold Spring Harb. Perspect. Biol. 2011, 3, a003947. [CrossRef] [PubMed]

14. Dolphin, A.C. Voltage-gated calcium channels: Their discovery, function and importance as drug targets. Brain Neurosci. Adv. 2018, 2, 2398212818794805. [CrossRef] [PubMed]

15. Tsien, R.W.; Lipscombe, D.; Madison, D.V.; Bley, K.R.; Fox, A.P. Multiple types of neuronal calcium channels and their selective modulation. Trends Neurosci. 1988, 11, 431-438. [CrossRef]

16. Nowycky, M.C.; Fox, A.P.; Tsien, R.W. Three types of neuronal calcium channel with different calcium agonist sensitivity. Nature 1985, 316, 440-443. [CrossRef]

17. Carbone, E.; Lux, H.D. A low voltage-activated, fully inactivating Ca channel in vertebrate sensory neurones. Nature 1984, 310, 501-502. [CrossRef]

18. Boland, L.M.; Morrill, J.A.; Bean, B.P. Omega-Conotoxin block of N-type calcium channels in frog and rat sympathetic neurons. J. Neurosci. 1994, 14, 5011-5027. [CrossRef] [PubMed]

19. Plummer, M.R.; Logothetis, D.E.; Hess, P. Elementary properties and pharmacological sensitivities of calcium channels in mammalian peripheral neurons. Neuron 1989, 2, 1453-1463. [CrossRef]

20. Mintz, I.M.; Venema, V.J.; Swiderek, K.M.; Lee, T.D.; Bean, B.P.; Adams, M.E. P-type calcium channels blocked by the spider toxin omega-Aga-IVA. Nature 1992, 355, 827-829. [CrossRef]

21. Llinas, R.; Sugimori, M.; Lin, J.W.; Cherksey, B. Blocking and isolation of a calcium channel from neurons in mammals and cephalopods utilizing a toxin fraction (FTX) from funnel-web spider poison. Proc. Natl. Acad. Sci. USA 1989, 86, 1689-1693. [CrossRef] [PubMed]

22. Randall, A.; Tsien, R.W. Pharmacological dissection of multiple types of $\mathrm{Ca}^{2+}$ channel currents in rat cerebellar granule neurons. J. Neurosci. 1995, 15, 2995-3012. [CrossRef]

23. Newcomb, R.; Szoke, B.; Palma, A.; Wang, G.; Chen, X.; Hopkins, W.; Cong, R.; Miller, J.; Urge, L.; Tarczy-Hornoch, K.; et al. Selective peptide antagonist of the class E calcium channel from the venom of the tarantula Hysterocrates gigas. Biochemistry 1998, 37, 15353-15362. [CrossRef] [PubMed]

24. Kimm, T.; Bean, B.P. Inhibition of A-type potassium current by the peptide toxin SNX-482. J. Neurosci. 2014, 34, 9182-9189. [CrossRef] [PubMed]

25. Splawski, I.; Timothy, K.W.; Decher, N.; Kumar, P.; Sachse, F.B.; Beggs, A.H.; Sanguinetti, M.C.; Keating, M.T. Severe arrhythmia disorder caused by cardiac L-type calcium channel mutations. Proc. Natl. Acad. Sci. USA 2005, 102, 8089-8096; discussion 8086-8088. [CrossRef] [PubMed]

26. Splawski, I.; Timothy, K.W.; Sharpe, L.M.; Decher, N.; Kumar, P.; Bloise, R.; Napolitano, C.; Schwartz, P.J.; Joseph, R.M.; Condouris, K.; et al. $\mathrm{Ca}(\mathrm{V}) 1.2$ calcium channel dysfunction causes a multisystem disorder including arrhythmia and autism. Cell 2004, 119, 19-31. [CrossRef] [PubMed]

27. Yarotskyy, V.; Gao, G.; Du, L.; Ganapathi, S.B.; Peterson, B.Z.; Elmslie, K.S. Roscovitine binds to novel L-channel (CaV1.2) sites that separately affect activation and inactivation. J. Biol. Chem. 2010, 285, 43-53. [CrossRef]

28. Yarotskyy, V.; Elmslie, K.S. Roscovitine, a cyclin-dependent kinase inhibitor, affects several gating mechanisms to inhibit cardiac L-type (Ca(V)1.2) calcium channels. Br. J. Pharmacol. 2007, 152, 386-395. [CrossRef] [PubMed]

29. Pasca, S.P.; Portmann, T.; Voineagu, I.; Yazawa, M.; Shcheglovitov, A.; Pasca, A.M.; Cord, B.; Palmer, T.D.; Chikahisa, S.; Nishino, S.; et al. Using iPSC-derived neurons to uncover cellular phenotypes associated with Timothy syndrome. Nat. Med. 2011, 17, 1657-1662. [CrossRef]

30. Ferreira, M.A.; O’Donovan, M.C.; Meng, Y.A.; Jones, I.R.; Ruderfer, D.M.; Jones, L.; Fan, J.; Kirov, G.; Perlis, R.H.; Green, E.K.; et al. Collaborative genome-wide association analysis supports a role for ANK3 and CACNA1C in bipolar disorder. Nat. Genet. 2008, 40, 1056-1058. [CrossRef] [PubMed]

31. Sklar, P.; Smoller, J.W.; Fan, J.; Ferreira, M.A.; Perlis, R.H.; Chambert, K.; Nimgaonkar, V.L.; McQueen, M.B.; Faraone, S.V.; Kirby, A.; et al. Whole-genome association study of bipolar disorder. Mol. Psychiatry 2008, 13, 558-569. [CrossRef]

32. Casamassima, F.; Huang, J.; Fava, M.; Sachs, G.S.; Smoller, J.W.; Cassano, G.B.; Lattanzi, L.; Fagerness, J.; Stange, J.P.; Perlis, R.H. Phenotypic effects of a bipolar liability gene among individuals with major depressive disorder. Am. J. Med. Genet. B Neuropsychiatr. Genet. 2010, 153B, 303-309. [CrossRef] [PubMed]

33. Green, E.K.; Grozeva, D.; Jones, I.; Jones, L.; Kirov, G.; Caesar, S.; Gordon-Smith, K.; Fraser, C.; Forty, L.; Russell, E.; et al. The bipolar disorder risk allele at CACNA1C also confers risk of recurrent major depression and of schizophrenia. Mol. Psychiatry 2010, 15, 1016-1022. [CrossRef]

34. Shi, J.; Potash, J.B.; Knowles, J.A.; Weissman, M.M.; Coryell, W.; Scheftner, W.A.; Lawson, W.B.; DePaulo, J.R., Jr.; Gejman, P.V.; Sanders, A.R.; et al. Genome-wide association study of recurrent early-onset major depressive disorder. Mol. Psychiatry 2011, 16, 193-201. [CrossRef] [PubMed]

35. Nyegaard, M.; Demontis, D.; Foldager, L.; Hedemand, A.; Flint, T.J.; Sorensen, K.M.; Andersen, P.S.; Nordentoft, M.; Werge, T.; Pedersen, C.B.; et al. CACNA1C (rs1006737) is associated with schizophrenia. Mol. Psychiatry 2010, 15, 119-121. [CrossRef]

36. Cross-Disorder Group of the Psychiatric Genomics Consortium. Identification of risk loci with shared effects on five major psychiatric disorders: A genome-wide analysis. Lancet 2013, 381, 1371-1379. [CrossRef] 
37. Schizophrenia Working Group of the Psychiatric Genomics Consortium. Biological insights from 108 schizophrenia-associated genetic loci. Nature 2014, 511, 421-427. [CrossRef] [PubMed]

38. Hori, H.; Yamamoto, N.; Fujii, T.; Teraishi, T.; Sasayama, D.; Matsuo, J.; Kawamoto, Y.; Kinoshita, Y.; Ota, M.; Hattori, K.; et al Effects of the CACNA1C risk allele on neurocognition in patients with schizophrenia and healthy individuals. Sci. Rep. 2012, 2, 634. [CrossRef]

39. Lencz, T.; Malhotra, A.K. Targeting the schizophrenia genome: A fast track strategy from GWAS to clinic. Mol. Psychiatry 2015, 20, 820-826. [CrossRef]

40. Krzyzewska, I.M.; Ensink, J.B.M.; Nawijn, L.; Mul, A.N.; Koch, S.B.; Venema, A.; Shankar, V.; Frijling, J.L.; Veltman, D.J.; Lindauer, R.J.L.; et al. Genetic variant in CACNA1C is associated with PTSD in traumatized police officers. Eur. J. Hum. Genet. 2018, 26, 247-257. [CrossRef]

41. Bavley, C.C.; Kabir, Z.D.; Walsh, A.P.; Kosovsky, M.; Hackett, J.; Sun, H.; Vazquez-Rosa, E.; Cintron-Perez, C.J.; Miller, E.; Koh, Y.; et al. Dopamine D1R-neuron cacna1c deficiency: A new model of extinction therapy-resistant post-traumatic stress. Mol. Psychiatry 2021, 26, 2286-2298. [CrossRef]

42. Baig, S.M.; Koschak, A.; Lieb, A.; Gebhart, M.; Dafinger, C.; Nurnberg, G.; Ali, A.; Ahmad, I.; Sinnegger-Brauns, M.J.; Brandt, N.; et al. Loss of $\mathrm{Ca}(\mathrm{v}) 1.3$ (CACNA1D) function in a human channelopathy with bradycardia and congenital deafness. Nat. Neurosci. 2011, 14, 77-84. [CrossRef] [PubMed]

43. Platzer, J.; Engel, J.; Schrott-Fischer, A.; Stephan, K.; Bova, S.; Chen, H.; Zheng, H.; Striessnig, J. Congenital deafness and sinoatrial node dysfunction in mice lacking class D L-type $\mathrm{Ca}^{2+}$ channels. Cell 2000, 102, 89-97. [CrossRef]

44. Ortner, N.J.; Kaserer, T.; Copeland, J.N.; Striessnig, J. De novo CACNA1D Ca(2+) channelopathies: Clinical phenotypes and molecular mechanism. Pflugers Arch. 2020, 472, 755-773. [CrossRef]

45. Ament, S.A.; Szelinger, S.; Glusman, G.; Ashworth, J.; Hou, L.; Akula, N.; Shekhtman, T.; Badner, J.A.; Brunkow, M.E.; Mauldin, D.E.; et al. Rare variants in neuronal excitability genes influence risk for bipolar disorder. Proc. Natl. Acad. Sci. USA 2015, 112, 3576-3581. [CrossRef]

46. Ross, J.; Gedvilaite, E.; Badner, J.A.; Erdman, C.; Baird, L.; Matsunami, N.; Leppert, M.; Xing, J.; Byerley, W. A Rare Variant in CACNA1D Segregates with 7 Bipolar I Disorder Cases in a Large Pedigree. Mol. Neuropsychiatry 2016, 2, 145-150. [CrossRef] [PubMed]

47. Zanetti, L.; Kilicarslan, I.; Netzer, M.; Babai, N.; Seitter, H.; Koschak, A. Function of cone and cone-related pathways in CaV1.4 IT mice. Sci. Rep. 2021, 11, 2732. [CrossRef] [PubMed]

48. Lodha, N.; Loucks, C.M.; Beaulieu, C.; Parboosingh, J.S.; Bech-Hansen, N.T. Congenital stationary night blindness: Mutation update and clinical variability. Adv. Exp. Med. Biol. 2012, 723, 371-379.

49. Inagaki, A.; Frank, C.A.; Usachev, Y.M.; Benveniste, M.; Lee, A. Pharmacological correction of gating defects in the voltage-gated $\mathrm{Ca}(\mathrm{v}) 2.1 \mathrm{Ca}(2)(+)$ channel due to a familial hemiplegic migraine mutation. Neuron 2014, 81, 91-102. [CrossRef] [PubMed]

50. Tottene, A.; Pivotto, F.; Fellin, T.; Cesetti, T.; van den Maagdenberg, A.M.; Pietrobon, D. Specific kinetic alterations of human CaV2.1 calcium channels produced by mutation S218L causing familial hemiplegic migraine and delayed cerebral edema and coma after minor head trauma. J. Biol. Chem. 2005, 280, 17678-17686. [CrossRef]

51. Waxman, S.G.; Zamponi, G.W. Regulating excitability of peripheral afferents: Emerging ion channel targets. Nat. Neurosci. 2014, 17, 153-163. [CrossRef]

52. Marger, F.; Gelot, A.; Alloui, A.; Matricon, J.; Ferrer, J.F.; Barrere, C.; Pizzoccaro, A.; Muller, E.; Nargeot, J.; Snutch, T.P.; et al. T-type calcium channels contribute to colonic hypersensitivity in a rat model of irritable bowel syndrome. Proc. Natl. Acad. Sci. USA 2011, 108, 11268-11273. [CrossRef]

53. Cizkova, D.; Marsala, J.; Lukacova, N.; Marsala, M.; Jergova, S.; Orendacova, J.; Yaksh, T.L. Localization of N-type Ca ${ }^{2+}$ channels in the rat spinal cord following chronic constrictive nerve injury. Exp. Brain Res. 2002, 147, 456-463. [CrossRef] [PubMed]

54. Jagodic, M.M.; Pathirathna, S.; Joksovic, P.M.; Lee, W.; Nelson, M.T.; Naik, A.K.; Su, P.; Jevtovic-Todorovic, V.; Todorovic, S.M. Upregulation of the T-type calcium current in small rat sensory neurons after chronic constrictive injury of the sciatic nerve. J. Neurophysiol. 2008, 99, 3151-3156. [CrossRef]

55. Jiang, Y.Q.; Andrade, A.; Lipscombe, D. Spinal morphine but not ziconotide or gabapentin analgesia is affected by alternative splicing of voltage-gated calcium channel CaV2.2 pre-mRNA. Mol. Pain 2013, 9, 67. [CrossRef] [PubMed]

56. Tedford, H.W.; Zamponi, G.W. Direct G protein modulation of Cav2 calcium channels. Pharmacol. Rev. 2006, 58, 837-862. [CrossRef]

57. Bell, T.J.; Thaler, C.; Castiglioni, A.J.; Helton, T.D.; Lipscombe, D. Cell-specific alternative splicing increases calcium channel current density in the pain pathway. Neuron 2004, 41, 127-138. [CrossRef]

58. Altier, C.; Dale, C.S.; Kisilevsky, A.E.; Chapman, K.; Castiglioni, A.J.; Matthews, E.A.; Evans, R.M.; Dickenson, A.H.; Lipscombe, D.; Vergnolle, N.; et al. Differential role of N-type calcium channel splice isoforms in pain. J. Neurosci. 2007, 27, 6363-6373. [CrossRef] [PubMed]

59. Nieto-Rostro, M.; Ramgoolam, K.; Pratt, W.S.; Kulik, A.; Dolphin, A.C. Ablation of alpha2delta-1 inhibits cell-surface trafficking of endogenous N-type calcium channels in the pain pathway in vivo. Proc. Natl. Acad. Sci. USA 2018, 115, E12043-E12052. [CrossRef] 
60. Luo, Z.D.; Chaplan, S.R.; Higuera, E.S.; Sorkin, L.S.; Stauderman, K.A.; Williams, M.E.; Yaksh, T.L. Upregulation of dorsal root ganglion (alpha)2(delta) calcium channel subunit and its correlation with allodynia in spinal nerve-injured rats. J. Neurosci. 2001, 21, 1868-1875. [CrossRef]

61. Bauer, C.S.; Nieto-Rostro, M.; Rahman, W.; Tran-Van-Minh, A.; Ferron, L.; Douglas, L.; Kadurin, I.; Sri Ranjan, Y.; FernandezAlacid, L.; Millar, N.S.; et al. The increased trafficking of the calcium channel subunit alpha2delta-1 to presynaptic terminals in neuropathic pain is inhibited by the alpha2delta ligand pregabalin. J. Neurosci. 2009, 29, 4076-4088. [CrossRef]

62. Iyer, A.; Marson, A. Pharmacotherapy of focal epilepsy. Expert Opin. Pharm. 2014, 15, 1543-1551. [CrossRef] [PubMed]

63. Hainsworth, A.H.; McNaughton, N.C.; Pereverzev, A.; Schneider, T.; Randall, A.D. Actions of sipatrigine, 202 W92 and lamotrigine on R-type and T-type $\mathrm{Ca}^{2+}$ channel currents. Eur. J. Pharmacol. 2003, 467, 77-80. [CrossRef]

64. Dibue, M.; Kamp, M.A.; Alpdogan, S.; Tevoufouet, E.E.; Neiss, W.F.; Hescheler, J.; Schneider, T. Cav 2.3 (R-type) calcium channels are critical for mediating anticonvulsive and neuroprotective properties of lamotrigine in vivo. Epilepsia 2013, 54, 1542-1550. [CrossRef] [PubMed]

65. Kuzmiski, J.B.; Barr, W.; Zamponi, G.W.; MacVicar, B.A. Topiramate inhibits the initiation of plateau potentials in CA1 neurons by depressing R-type calcium channels. Epilepsia 2005, 46, 481-489. [CrossRef]

66. Ernst, W.L.; Zhang, Y.; Yoo, J.W.; Ernst, S.J.; Noebels, J.L. Genetic enhancement of thalamocortical network activity by elevating alpha 1g-mediated low-voltage-activated calcium current induces pure absence epilepsy. J. Neurosci. 2009, 29, 1615-1625. [CrossRef] [PubMed]

67. Talley, E.M.; Solorzano, G.; Depaulis, A.; Perez-Reyes, E.; Bayliss, D.A. Low-voltage-activated calcium channel subunit expression in a genetic model of absence epilepsy in the rat. Brain Res. Mol. Brain Res. 2000, 75, 159-165. [CrossRef]

68. Powell, K.L.; Cain, S.M.; Ng, C.; Sirdesai, S.; David, L.S.; Kyi, M.; Garcia, E.; Tyson, J.R.; Reid, C.A.; Bahlo, M.; et al. A Cav3.2 T-type calcium channel point mutation has splice-variant-specific effects on function and segregates with seizure expression in a polygenic rat model of absence epilepsy. J. Neurosci. 2009, 29, 371-380. [CrossRef]

69. Zamponi, G.W.; Lory, P.; Perez-Reyes, E. Role of voltage-gated calcium channels in epilepsy. Pflugers Arch. 2010, 460, $395-403$. [CrossRef] [PubMed]

70. Heron, S.E.; Khosravani, H.; Varela, D.; Bladen, C.; Williams, T.C.; Newman, M.R.; Scheffer, I.E.; Berkovic, S.F.; Mulley, J.C.; Zamponi, G.W. Extended spectrum of idiopathic generalized epilepsies associated with CACNA1H functional variants. Ann. Neurol. 2007, 62, 560-568. [CrossRef]

71. Vitko, I.; Bidaud, I.; Arias, J.M.; Mezghrani, A.; Lory, P.; Perez-Reyes, E. The I-II loop controls plasma membrane expression and gating of $\mathrm{Ca}(\mathrm{v}) 3.2 \mathrm{~T}$-type $\mathrm{Ca}^{2+}$ channels: A paradigm for childhood absence epilepsy mutations. J. Neurosci. 2007, 27, 322-330. [CrossRef] [PubMed]

72. Khosravani, H.; Altier, C.; Simms, B.; Hamming, K.S.; Snutch, T.P.; Mezeyova, J.; McRory, J.E.; Zamponi, G.W. Gating effects of mutations in the Cav3.2 T-type calcium channel associated with childhood absence epilepsy. J. Biol. Chem. 2004, 279, 9681-9684. [CrossRef]

73. Splawski, I.; Yoo, D.S.; Stotz, S.C.; Cherry, A.; Clapham, D.E.; Keating, M.T. CACNA1H mutations in Autism. spectrum disorders. J. Biol. Chem. 2006, 281, 22085-22091. [CrossRef] [PubMed]

74. El Ghaleb, Y.; Schneeberger, P.E.; Fernandez-Quintero, M.L.; Geisler, S.M.; Pelizzari, S.; Polstra, A.M.; van Hagen, J.M.; Denecke, J.; Campiglio, M.; Liedl, K.R.; et al. CACNA1I gain-of-function mutations differentially affect channel gating and cause neurodevelopmental disorders. Brain 2021, 144, 2092-2106. [CrossRef]

75. Dolphin, A.C. Voltage-gated calcium channels and their auxiliary subunits: Physiology and pathophysiology and pharmacology. J. Physiol. 2016, 594, 5369-5390. [CrossRef] [PubMed]

76. Dolphin, A.C. Calcium channel auxiliary alpha2delta and beta subunits: Trafficking and one step beyond. Nat. Rev. Neurosci. 2012, 13, 542-555. [CrossRef]

77. Ertel, E.A.; Campbell, K.P.; Harpold, M.M.; Hofmann, F.; Mori, Y.; Perez-Reyes, E.; Schwartz, A.; Snutch, T.P.; Tanabe, T.; Birnbaumer, L.; et al. Nomenclature of voltage-gated calcium channels. Neuron 2000, 25, 533-535. [CrossRef]

78. Dolphin, A.C.; Lee, A. Presynaptic calcium channels: Specialized control of synaptic neurotransmitter release. Nat. Rev. Neurosci. 2020, 21, 213-229. [CrossRef]

79. Dai, S.; Hall, D.D.; Hell, J.W. Supramolecular assemblies and localized regulation of voltage-gated ion channels. Physiol Rev. 2009, 89, 411-452. [CrossRef]

80. Harvey, R.D.; Hell, J.W. CaV1.2 signaling complexes in the heart. J. Mol. Cell Cardiol. 2013, 58, 143-152. [CrossRef]

81. Patriarchi, T.; Buonarati, O.R.; Hell, J.W. Postsynaptic localization and regulation of AMPA receptors and Cav1.2 by beta2 adrenergic receptor/PKA and Ca(2+)/CaMKII signaling. EMBO J. 2018, 37, e99771. [CrossRef] [PubMed]

82. Wild, A.R.; Dell'Acqua, M.L. Potential for therapeutic targeting of AKAP signaling complexes in nervous system disorders. Pharmacol. Ther. 2018, 185, 99-121. [CrossRef]

83. Calin-Jageman, I.; Lee, A. Ca(v)1 L-type Ca ${ }^{2+}$ channel signaling complexes in neurons. J. Neurochem. 2008, 105, 573-583. [CrossRef] [PubMed]

84. Nanou, E.; Catterall, W.A. Calcium Channels, Synaptic Plasticity, and Neuropsychiatric Disease. Neuron 2018, 98 , 466-481. [CrossRef] [PubMed] 
85. Hell, J.W.; Westenbroek, R.E.; Warner, C.; Ahlijanian, M.K.; Prystay, W.; Gilbert, M.M.; Snutch, T.P.; Catterall, W.A. Identification and differential subcellular localization of the neuronal class C and class D L-type calcium channel alpha 1 subunits. J. Cell Biol. 1993, 123, 949-962. [CrossRef]

86. Wild, A.R.; Sinnen, B.L.; Dittmer, P.J.; Kennedy, M.J.; Sather, W.A.; Dell'Acqua, M.L. Synapse-to-Nucleus Communication through NFAT Is Mediated by L-type Ca(2+) Channel Ca(2+) Spike Propagation to the Soma. Cell Rep. 2019, 26, 3537-3550.e4. [CrossRef] [PubMed]

87. Oliveria, S.F.; Dell'Acqua, M.L.; Sather, W.A. AKAP79/150 anchoring of calcineurin controls neuronal L-type Ca ${ }^{2+}$ channel activity and nuclear signaling. Neuron 2007, 55, 261-275. [CrossRef] [PubMed]

88. Wheeler, D.G.; Groth, R.D.; Ma, H.; Barrett, C.F.; Owen, S.F.; Safa, P.; Tsien, R.W. Ca(V)1 and Ca(V)2 channels engage distinct modes of $\mathrm{Ca}(2+)$ signaling to control CREB-dependent gene expression. Cell 2012, 149, 1112-1124. [CrossRef]

89. Patriarchi, T.; Qian, H.; Di Biase, V.; Malik, Z.A.; Chowdhury, D.; Price, J.L.; Hammes, E.A.; Buonarati, O.R.; Westenbroek, R.E.; Catterall, W.A.; et al. Phosphorylation of Cav1.2 on S1928 uncouples the L-type $\mathrm{Ca}^{2+}$ channel from the beta2 adrenergic receptor. EMBO J. 2016, 35, 1330-1345. [CrossRef] [PubMed]

90. Sridharan, P.S.; Lu, Y.; Rice, R.C.; Pieper, A.A.; Rajadhyaksha, A.M. Loss of Cav1.2 channels impairs hippocampal theta burst stimulation-induced long-term potentiation. Channels 2020, 14, 287-293. [CrossRef]

91. Berkefeld, H.; Sailer, C.A.; Bildl, W.; Rohde, V.; Thumfart, J.O.; Eble, S.; Klugbauer, N.; Reisinger, E.; Bischofberger, J.; Oliver, D.; et al. BKCa-Cav channel complexes mediate rapid and localized $\mathrm{Ca}^{2+}$-activated $\mathrm{K}+$ signaling. Science 2006, 314, 615-620. [CrossRef]

92. Stanika, R.; Campiglio, M.; Pinggera, A.; Lee, A.; Striessnig, J.; Flucher, B.E.; Obermair, G.J. Splice variants of the CaV1.3 L-type calcium channel regulate dendritic spine morphology. Sci. Rep. 2016, 6, 34528. [CrossRef]

93. Olson, P.A.; Tkatch, T.; Hernandez-Lopez, S.; Ulrich, S.; Ilijic, E.; Mugnaini, E.; Zhang, H.; Bezprozvanny, I.; Surmeier, D.J. G-protein-coupled receptor modulation of striatal CaV1.3 L-type $\mathrm{Ca}^{2+}$ channels is dependent on a Shank-binding domain. J. Neurosci. 2005, 25, 1050-1062. [CrossRef] [PubMed]

94. Plotkin, J.L.; Shen, W.; Rafalovich, I.; Sebel, L.E.; Day, M.; Chan, C.S.; Surmeier, D.J. Regulation of dendritic calcium release in striatal spiny projection neurons. J. Neurophysiol. 2013, 110, 2325-2336. [CrossRef] [PubMed]

95. Pangrsic, T.; Singer, J.H.; Koschak, A. Voltage-Gated Calcium Channels: Key Players in Sensory Coding in the Retina and the Inner Ear. Physiol. Rev. 2018, 98, 2063-2096. [CrossRef] [PubMed]

96. Brandt, A.; Khimich, D.; Moser, T. Few CaV1.3 channels regulate the exocytosis of a synaptic vesicle at the hair cell ribbon synapse. J. Neurosci. 2005, 25, 11577-11585. [CrossRef]

97. Lodha, N.; Bonfield, S.; Orton, N.C.; Doering, C.J.; McRory, J.E.; Mema, S.C.; Rehak, R.; Sauve, Y.; Tobias, R.; Stell, W.K.; et al. Congenital stationary night blindness in mice-A tale of two Cacna1f mutants. Adv. Exp. Med. Biol. 2010, 664, 549-558.

98. Sudhof, T.C. The presynaptic active zone. Neuron 2012, 75, 11-25. [CrossRef]

99. Wheeler, D.B.; Randall, A.; Tsien, R.W. Roles of N-type and Q-type Ca ${ }^{2+}$ channels in supporting hippocampal synaptic transmission. Science 1994, 264, 107-111. [CrossRef]

100. Lazarevic, V.; Pothula, S.; Andres-Alonso, M.; Fejtova, A. Molecular mechanisms driving homeostatic plasticity of neurotransmitter release. Front. Cell Neurosci. 2013, 7, 244. [CrossRef]

101. Cao, Y.Q.; Piedras-Renteria, E.S.; Smith, G.B.; Chen, G.; Harata, N.C.; Tsien, R.W. Presynaptic Ca ${ }^{2+}$ channels compete for channel type-preferring slots in altered neurotransmission arising from $\mathrm{Ca}^{2+}$ channelopathy. Neuron 2004, 43, 387-400. [CrossRef] [PubMed]

102. Sutton, K.G.; McRory, J.E.; Guthrie, H.; Murphy, T.H.; Snutch, T.P. P/Q-type calcium channels mediate the activity-dependent feedback of syntaxin-1A. Nature 1999, 401, 800-804. [CrossRef] [PubMed]

103. Vecchia, D.; Tottene, A.; van den Maagdenberg, A.M.; Pietrobon, D. Abnormal cortical synaptic transmission in CaV2.1 knockin mice with the S218L missense mutation which causes a severe familial hemiplegic migraine syndrome in humans. Front. Cell Neurosci. 2015, 9, 8. [CrossRef] [PubMed]

104. Perez-Reyes, E. Molecular physiology of low-voltage-activated t-type calcium channels. Physiol. Rev. 2003, 83, 117-161. [PubMed]

105. Molineux, M.L.; McRory, J.E.; McKay, B.E.; Hamid, J.; Mehaffey, W.H.; Rehak, R.; Snutch, T.P.; Zamponi, G.W.; Turner, R.W. Specific T-type calcium channel isoforms are associated with distinct burst phenotypes in deep cerebellar nuclear neurons. Proc. Natl. Acad. Sci. USA 2006, 103, 5555-5560. [CrossRef]

106. Chemin, J.; Monteil, A.; Bourinet, E.; Nargeot, J.; Lory, P. Alternatively spliced alpha(1G) $(\mathrm{Ca}(\mathrm{V}) 3.1)$ intracellular loops promote specific T-type $\mathrm{Ca}(2+)$ channel gating properties. Biophys. J. 2001, 80, 1238-1250. [CrossRef]

107. Bigos, K.L.; Mattay, V.S.; Callicott, J.H.; Straub, R.E.; Vakkalanka, R.; Kolachana, B.; Hyde, T.M.; Lipska, B.K.; Kleinman, J.E.; Weinberger, D.R. Genetic variation in CACNA1C affects brain circuitries related to mental illness. Arch. Gen. Psychiatry 2010, 67, 939-945. [CrossRef]

108. Thimm, M.; Kircher, T.; Kellermann, T.; Markov, V.; Krach, S.; Jansen, A.; Zerres, K.; Eggermann, T.; Stocker, T.; Shah, N.J.; et al. Effects of a CACNA1C genotype on attention networks in healthy individuals. Psychol Med. 2011, 41, 1551-1561. [CrossRef]

109. Krug, A.; Nieratschker, V.; Markov, V.; Krach, S.; Jansen, A.; Zerres, K.; Eggermann, T.; Stocker, T.; Shah, N.J.; Treutlein, J.; et al. Effect of CACNA1C rs1006737 on neural correlates of verbal fluency in healthy individuals. Neuroimage 2010, 49, 1831-1836. [CrossRef] 
110. Vahdani, B.; Armani Kian, A.; Esmaeilzadeh, A.; Zenoozian, S.; Yousefi, V.; Mazloomzadeh, S. Adjunctive Raloxifene and Isradipine Improve Cognitive Functioning in Patients With Schizophrenia: A Pilot Study. J. Clin. PsychoPharmacol. 2020, 40, 457-463. [CrossRef]

111. Clark, M.B.; Wrzesinski, T.; Garcia, A.B.; Hall, N.A.L.; Kleinman, J.E.; Hyde, T.; Weinberger, D.R.; Harrison, P.J.; Haerty, W.; Tunbridge, E.M. Long-read sequencing reveals the complex splicing profile of the psychiatric risk gene CACNA1C in human brain. Mol. Psychiatry 2020, 25, 37-47. [CrossRef] [PubMed]

112. Seitter, H.; Koschak, A. Relevance of tissue specific subunit expression in channelopathies. Neuropharmacology 2018, 132, 58-70. [CrossRef] [PubMed]

113. Ostacher, M.J.; Iosifescu, D.V.; Hay, A.; Blumenthal, S.R.; Sklar, P.; Perlis, R.H. Pilot investigation of isradipine in the treatment of bipolar depression motivated by genome-wide association. Bipolar Disord 2014, 16, 199-203. [CrossRef] [PubMed]

114. Yarotskyy, V.; Gao, G.; Peterson, B.Z.; Elmslie, K.S. The Timothy syndrome mutation of cardiac CaV1.2 (L-type) channels: Multiple altered gating mechanisms and pharmacological restoration of inactivation. J. Physiol. 2009, 587, 551-565. [CrossRef] [PubMed]

115. Li, B.; Tadross, M.R.; Tsien, R.W. Sequential ionic and conformational signaling by calcium channels drives neuronal gene expression. Science 2016, 351, 863-867. [CrossRef] [PubMed]

116. Hofer, N.T.; Tuluc, P.; Ortner, N.J.; Nikonishyna, Y.V.; Fernandes-Quintero, M.L.; Liedl, K.R.; Flucher, B.E.; Cox, H.; Striessnig, J. Biophysical classification of a CACNA1D de novo mutation as a high-risk mutation for a severe neurodevelopmental disorder. Mol. Autism. 2020, 11, 4.

117. Lu, A.T.; Dai, X.; Martinez-Agosto, J.A.; Cantor, R.M. Support for calcium channel gene defects in Autism. spectrum disorders. Mol. Autism. 2012, 3, 18. [CrossRef]

118. Strom, S.P.; Stone, J.L.; Ten Bosch, J.R.; Merriman, B.; Cantor, R.M.; Geschwind, D.H.; Nelson, S.F. High-density SNP association study of the 17q21 chromosomal region linked to Autism. identifies CACNA1G as a novel candidate gene. Mol. Psychiatry 2010, 15, 996-1005. [CrossRef]

119. Strawn, J.R.; Geracioti, T.D., Jr. The treatment of generalized anxiety disorder with pregabalin, an atypical anxiolytic. Neuropsychiatr. Dis. Treat. 2007, 3, 237-243. [CrossRef] [PubMed]

120. Duval, E.R.; Javanbakht, A.; Liberzon, I. Neural circuits in anxiety and stress disorders: A focused review. Ther. Clin. Risk Manag. 2015, 11, 115-126.

121. Shinnick-Gallagher, P.; McKernan, M.G.; Xie, J.; Zinebi, F. L-type voltage-gated calcium channels are involved in the in vivo and in vitro expression of fear conditioning. Ann. N. Y. Acad. Sci. 2003, 985, 135-149. [PubMed]

122. Fulga, I.G.; Stroescu, V. Experimental reseArch. on the effect of calcium channel blockers nifedipine and verapamil on the anxiety in mice. Rom. J. Physiol. 1997, 34, 127-136. [PubMed]

123. Busquet, P.; Nguyen, N.K.; Schmid, E.; Tanimoto, N.; Seeliger, M.W.; Ben-Yosef, T.; Mizuno, F.; Akopian, A.; Striessnig, J.; Singewald, N. CaV1.3 L-type $\mathrm{Ca}^{2+}$ channels modulate depression-like behaviour in mice independent of deaf phenotype. Int. J. Neuropsychopharmacol. 2010, 13, 499-513. [CrossRef] [PubMed]

124. Saegusa, H.; Kurihara, T.; Zong, S.; Kazuno, A.; Matsuda, Y.; Nonaka, T.; Han, W.; Toriyama, H.; Tanabe, T. Suppression of inflammatory and neuropathic pain symptoms in mice lacking the $\mathrm{N}-$ type $\mathrm{Ca}^{2+}$ channel. EMBO J. 2001, 20, 2349-2356. [CrossRef] [PubMed]

125. Sulzer, D.; Surmeier, D.J. Neuronal vulnerability, pathogenesis, and Parkinson's disease. Mov. Disord. 2013, 28, 715-724. [CrossRef]

126. Zahodne, L.B.; Fernandez, H.H. Pathophysiology and treatment of psychosis in Parkinson's disease: A review. Drugs Aging 2008, 25, 665-682. [CrossRef]

127. Connolly, B.S.; Lang, A.E. Pharmacological treatment of Parkinson disease: A review. JAMA 2014, 311, 1670-1683. [CrossRef] [PubMed]

128. Kalia, L.V.; Lang, A.E. Parkinson's disease. Lancet 2015, 386, 896-912. [CrossRef]

129. Nuytemans, K.; Theuns, J.; Cruts, M.; Van Broeckhoven, C. Genetic etiology of Parkinson disease associated with mutations in the SNCA, PARK2, PINK1, PARK7, and LRRK2 genes: A mutation update. Hum. Mutat. 2010, 31, 763-780. [CrossRef]

130. Abdel-Salam, O.M. The paths to neurodegeneration in genetic Parkinson's disease. CNS Neurol. Disord.-Drug Targets 2014, 13, 1485-1512. [CrossRef] [PubMed]

131. Becker, C.; Jick, S.S.; Meier, C.R. Use of antihypertensives and the risk of Parkinson disease. Neurology 2008, 70, 1438-1444. [CrossRef] [PubMed]

132. Pasternak, B.; Svanstrom, H.; Nielsen, N.M.; Fugger, L.; Melbye, M.; Hviid, A. Use of calcium channel blockers and Parkinson'sdisease. Am. J. Epidemiol. 2012, 175, 627-635. [CrossRef] [PubMed]

133. Ritz, B.; Rhodes, S.L.; Qian, L.; Schernhammer, E.; Olsen, J.H.; Friis, S. L-type calcium channel blockers and Parkinson disease in Denmark. Ann. Neurol. 2010, 67, 600-606. [PubMed]

134. Liss, B.; Striessnig, J. The Potential of L-Type Calcium Channels as a Drug Target for Neuroprotective Therapy in Parkinson's Disease. Annu. Rev. Pharmacol. Toxicol. 2019, 59, 263-289. [CrossRef] [PubMed]

135. Putzier, I.; Kullmann, P.H.; Horn, J.P.; Levitan, E.S. Cav1.3 channel voltage dependence, not $\mathrm{Ca}^{2+}$ selectivity, drives pacemaker activity and amplifies bursts in nigral dopamine neurons. J. Neurosci. 2009, 29, 15414-15419. [CrossRef]

136. Chan, C.S.; Gertler, T.S.; Surmeier, D.J. A molecular basis for the increased vulnerability of substantia nigra dopamine neurons in aging and Parkinson's disease. Mov. Disord. 2010, 25 (Suppl. 1), S63-S70. [CrossRef] 
137. Guzman, J.N.; Sanchez-Padilla, J.; Wokosin, D.; Kondapalli, J.; Ilijic, E.; Schumacker, P.T.; Surmeier, D.J. Oxidant stress evoked by pacemaking in dopaminergic neurons is attenuated by DJ-1. Nature 2010, 468, 696-700. [CrossRef] [PubMed]

138. Hurley, M.J.; Brandon, B.; Gentleman, S.M.; Dexter, D.T. Parkinson's disease is associated with altered expression of CaV1 channels and calcium-binding proteins. Brain 2013, 136, 2077-2097. [CrossRef] [PubMed]

139. Xu, W.; Lipscombe, D. Neuronal $\mathrm{Ca}(\mathrm{V}) 1.3 a l p h a(1)$ L-type channels activate at relatively hyperpolarized membrane potentials and are incompletely inhibited by dihydropyridines. J. Neurosci. 2001, 21, 5944-5951. [CrossRef]

140. Wang, Y.; Tang, S.; Harvey, K.E.; Salyer, A.E.; Li, T.A.; Rantz, E.K.; Lill, M.A.; Hockerman, G.H. Molecular Determinants of the Differential Modulation of Cav1.2 and Cav1.3 by Nifedipine and FPL 64176. Mol. Pharmacol. 2018, 94, 973-983. [CrossRef]

141. Lipscombe, D.; Helton, T.D.; Xu, W. L-type calcium channels: The low down. J. Neurophysiol. 2004, 92, 2633-2641. [CrossRef] [PubMed]

142. Parkinson Study, G. Phase II safety, tolerability, and dose selection study of isradipine as a potential disease-modifying intervention in early Parkinson's disease (STEADY-PD). Mov. Disord. 2013, 28, 1823-1831. [CrossRef] [PubMed]

143. Parkinson Study Group STEADY-PD III Investigators. Isradipine Versus Placebo in Early Parkinson Disease: A Randomized Trial. Ann. Intern. Med. 2020, 172, 591-598. [CrossRef] [PubMed]

144. Venuto, C.S.; Yang, L.; Javidnia, M.; Oakes, D.; James Surmeier, D.; Simuni, T. Isradipine plasma pharmacokinetics and exposureresponse in early Parkinson's disease. Ann. Clin. Transl. Neurol. 2021, 8, 603-612. [CrossRef] [PubMed]

145. Tai, C.H.; Yang, Y.C.; Pan, M.K.; Huang, C.S.; Kuo, C.C. Modulation of subthalamic T-type Ca(2+) channels remedies locomotor deficits in a rat model of Parkinson disease. J. Clin. Investig. 2011, 121, 3289-3305. [CrossRef] [PubMed]

146. Tabata, Y.; Imaizumi, Y.; Sugawara, M.; Andoh-Noda, T.; Banno, S.; Chai, M.; Sone, T.; Yamazaki, K.; Ito, M.; Tsukahara, K.; et al T-type Calcium Channels Determine the Vulnerability of Dopaminergic Neurons to Mitochondrial Stress in Familial Parkinson Disease. Stem Cell Reports 2018, 11, 1171-1184. [CrossRef]

147. Weiss, N.; Zamponi, G.W. T-Type Channel Druggability at a Crossroads. ACS Chem. Neurosci. 2019, 10, 1124-1126. [CrossRef]

148. Weiss, N.; Zamponi, G.W. T-type calcium channels: From molecule to therapeutic opportunities. Int. J. BioChem. Cell Biol. 2019, 108, 34-39. [CrossRef]

149. Ortner, N.J. Voltage-Gated Ca(2+) Channels in Dopaminergic Substantia Nigra Neurons: Therapeutic Targets for Neuroprotection in Parkinson's Disease? Front. Synaptic Neurosci. 2021, 13, 636103. [CrossRef] [PubMed]

150. Striessnig, J.; Bolz, H.J.; Koschak, A. Channelopathies in Cav1.1, Cav1.3, and Cav1.4 voltage-gated L-type Ca ${ }^{2+}$ channels. Pflugers Arch. 2010, 460, 361-374. [CrossRef]

151. Martinez-Rivera, A.; Hao, J.; Tropea, T.F.; Giordano, T.P.; Kosovsky, M.; Rice, R.C.; Lee, A.; Huganir, R.L.; Striessnig, J.; Addy, N.A.; et al. Enhancing VTA Cav1.3 L-type $\mathrm{Ca}(2+)$ channel activity promotes cocaine and mood-related behaviors via overlapping AMPA receptor mechanisms in the nucleus accumbens. Mol. Psychiatry 2017, 22, 1735-1745. [CrossRef] [PubMed]

152. Ye, Q.; Zhang, Z.; Zhang, W.; Ding, Y.; Zhao, F.; Zhang, J.; Song, Y. Investigation of the Selectivity of L-Type Voltage-Gated Calcium Channels 1.3 for Pyrimidine-2,4,6-Triones Derivatives Based on Molecular Dynamics Simulation. Molecules 2020, 25, 5440. [CrossRef]

153. Kang, S.; Cooper, G.; Dunne, S.F.; Dusel, B.; Luan, C.H.; Surmeier, D.J.; Silverman, R.B. CaV1.3-selective L-type calcium channel antagonists as potential new therapeutics for Parkinson's disease. Nat. Commun. 2012, 3, 1146. [CrossRef] [PubMed]

154. Cooper, G.; Kang, S.; Perez-Rosello, T.; Guzman, J.N.; Galtieri, D.; Xie, Z.; Kondapalli, J.; Mordell, J.; Silverman, R.B.; Surmeier, D.J. A Single Amino Acid Determines the Selectivity and Efficacy of Selective Negative Allosteric Modulators of CaV1.3 L-Type Calcium Channels. ACS Chem. Biol. 2020, 15, 2539-2550. [CrossRef]

155. Huang, H.; Ng, C.Y.; Yu, D.; Zhai, J.; Lam, Y.; Soong, T.W. Modest CaV1.342-selective inhibition by compound 8 is beta-subunit dependent. Nat. Commun. 2014, 5, 4481. [CrossRef]

156. Ortner, N.J.; Bock, G.; Vandael, D.H.; Mauersberger, R.; Draheim, H.J.; Gust, R.; Carbone, E.; Tuluc, P.; Striessnig, J. Pyrimidine2,4,6-triones are a new class of voltage-gated L-type $\mathrm{Ca}^{2+}$ channel activators. Nat. Commun. 2014, 5, 3897. [CrossRef] [PubMed]

157. Degoulet, M.; Stelly, C.E.; Ahn, K.C.; Morikawa, H. L-type Ca(2)(+) channel blockade with antihypertensive medication disrupts VTA synaptic plasticity and drug-associated contextual memory. Mol. Psychiatry 2016, 21, 394-402. [CrossRef] [PubMed]

158. Basbaum, A.I.; Bautista, D.M.; Scherrer, G.; Julius, D. Cellular and molecular mechanisms of pain. Cell 2009, 139, 267-284. [CrossRef]

159. Hendrich, J.; Bauer, C.S.; Dolphin, A.C. Chronic pregabalin inhibits synaptic transmission between rat dorsal root ganglion and dorsal horn neurons in culture. Channels 2012, 6, 124-132. [CrossRef] [PubMed]

160. Rauck, R.L.; Wallace, M.S.; Burton, A.W.; Kapural, L.; North, J.M. Intrathecal ziconotide for neuropathic pain: A review. Pain Pract. 2009, 9, 327-337. [CrossRef] [PubMed]

161. Staats, P.S.; Yearwood, T.; Charapata, S.G.; Presley, R.W.; Wallace, M.S.; Byas-Smith, M.; Fisher, R.; Bryce, D.A.; Mangieri, E.A.; Luther, R.R.; et al. Intrathecal ziconotide in the treatment of refractory pain in patients with cancer or AIDS: A randomized controlled trial. JAMA 2004, 291, 63-70. [CrossRef] [PubMed]

162. Rauck, R.L.; Wallace, M.S.; Leong, M.S.; Minehart, M.; Webster, L.R.; Charapata, S.G.; Abraham, J.E.; Buffington, D.E.; Ellis, D.; Kartzinel, R.; et al. A randomized, double-blind, placebo-controlled study of intrathecal ziconotide in adults with severe chronic pain. J. Pain Symptom Manag. 2006, 31, 393-406. [CrossRef] [PubMed] 
163. Wallace, M.S.; Charapata, S.G.; Fisher, R.; Byas-Smith, M.; Staats, P.S.; Mayo, M.; McGuire, D.; Ellis, D.; Ziconotide Nonmalignant Pain Study, G. Intrathecal ziconotide in the treatment of chronic nonmalignant pain: A randomized, double-blind, placebocontrolled clinical trial. Neuromodulation 2006, 9, 75-86. [CrossRef] [PubMed]

164. Zamponi, G.W.; Feng, Z.P.; Zhang, L.; Pajouhesh, H.; Ding, Y.; Belardetti, F.; Pajouhesh, H.; Dolphin, D.; Mitscher, L.A.; Snutch, T.P. Scaffold-based design and synthesis of potent N-type calcium channel blockers. Bioorganic Med. Chem. Lett. 2009, 19, 6467-6472. [CrossRef]

165. Swensen, A.M.; Herrington, J.; Bugianesi, R.M.; Dai, G.; Haedo, R.J.; Ratliff, K.S.; Smith, M.M.; Warren, V.A.; Arneric, S.P.; Eduljee, C.; et al. Characterization of the substituted N-triazole oxindole TROX-1, a small-molecule, state-dependent inhibitor of Ca(V)2 calcium channels. Mol. Pharmacol. 2012, 81, 488-497. [CrossRef]

166. Mathela, C.S.; Chanotiya, C.S.; Sammal, S.S.; Pant, A.K.; Pandey, S. Compositional diversity of terpenoids in the Himalayan Valeriana genera. Chem. Biodivers 2005, 2, 1174-1182. [CrossRef]

167. Jiang, H.H.; Dong, W.; Zhou, J.; Hu, J.M.; Yang, J.; Nian, Y. Ca(v)2.2 and Ca(v)3.1 calcium channel inhibitors from Valeriana jatamansi Jones. Rsc Adv. 2017, 7, 45878-45884. [CrossRef]

168. Subasinghe, N.L.; Wall, M.J.; Winters, M.P.; Qin, N.; Lubin, M.L.; Finley, M.F.; Brandt, M.R.; Neeper, M.P.; Schneider, C.R.; Colburn, R.W.; et al. A novel series of pyrazolylpiperidine N-type calcium channel blockers. Bioorganic Med. Chem. Lett. 2012, 22, 4080-4083. [CrossRef]

169. Shao, P.P.; Ye, F.; Chakravarty, P.K.; Varughese, D.J.; Herrington, J.B.; Dai, G.; Bugianesi, R.M.; Haedo, R.J.; Swensen, A.M.; Warren, V.A.; et al. Aminopiperidine sulfonamide Cav2.2 channel inhibitors for the treatment of chronic pain. J. Med. Chem. 2012, 55, 9847-9855. [CrossRef]

170. Chen, X.; Liu, D.; Zhou, D.; Si, Y.; Xu, D.; Stamatkin, C.W.; Ghozayel, M.K.; Ripsch, M.S.; Obukhov, A.G.; White, F.A.; et al Small-molecule CaValpha1CaVbeta antagonist suppresses neuronal voltage-gated calcium-channel trafficking. Proc. Natl. Acad. Sci. USA 2018, 115, E10566-E10575. [CrossRef]

171. Van Petegem, F.; Duderstadt, K.E.; Clark, K.A.; Wang, M.; Minor, D.L., Jr. Alanine-scanning mutagenesis defines a conserved energetic hotspot in the CaValpha1 AID-CaVbeta interaction site that is critical for channel modulation. Structure 2008, 16, 280-294. [CrossRef]

172. Campiglio, M.; Coste de Bagneaux, P.; Ortner, N.J.; Tuluc, P.; Van Petegem, F.; Flucher, B.E. STAC proteins associate to the IQ domain of CaV1.2 and inhibit calcium-dependent inactivation. Proc. Natl. Acad. Sci. USA 2018, 115, 1376-1381. [CrossRef]

173. Horstick, E.J.; Linsley, J.W.; Dowling, J.J.; Hauser, M.A.; McDonald, K.K.; Ashley-Koch, A.; Saint-Amant, L.; Satish, A.; Cui, W.W.; Zhou, W.; et al. Stac3 is a component of the excitation-contraction coupling machinery and mutated in Native American myopathy. Nat. Commun. 2013, 4, 1952. [CrossRef] [PubMed]

174. Moshe, S.L.; Perucca, E.; Ryvlin, P.; Tomson, T. Epilepsy: New advances. Lancet 2015, 385, 884-898. [CrossRef]

175. Herman, S.T. Epilepsy after brain insult: Targeting epileptogenesis. Neurology 2002, 59 (Suppl. S5), S21-S26. [CrossRef]

176. Noebels, J.L. The biology of epilepsy genes. Annu. Rev. Neurosci. 2003, 26, 599-625. [CrossRef] [PubMed]

177. Heron, S.E.; Scheffer, I.E.; Berkovic, S.F.; Dibbens, L.M.; Mulley, J.C. Channelopathies in idiopathic epilepsy. Neurotherapeutics 2007, 4, 295-304. [CrossRef] [PubMed]

178. Khosravani, H.; Zamponi, G.W. Voltage-gated calcium channels and idiopathic generalized epilepsies. Physiol. Rev. 2006, 86, 941-966. [CrossRef] [PubMed]

179. Meisel, C.; Loddenkemper, T. Seizure prediction and intervention. Neuropharmacology 2020, 172, 107898. [CrossRef]

180. Perucca, E.; Tomson, T. The pharmacological treatment of epilepsy in adults. Lancet. Neurol. 2011, 10, 446-456. [CrossRef]

181. Loscher, W.; Schmidt, D. Modern antiepileptic drug development has failed to deliver: Ways out of the current dilemma. Epilepsia 2011, 52, 657-678. [CrossRef] [PubMed]

182. Brodie, M.J.; Barry, S.J.; Bamagous, G.A.; Norrie, J.D.; Kwan, P. Patterns of treatment response in newly diagnosed epilepsy. Neurology 2012, 78, 1548-1554. [CrossRef] [PubMed]

183. Ryvlin, P.; Cross, J.H.; Rheims, S. Epilepsy surgery in children and adults. Lancet Neurol. 2014, 13, 1114-1126. [CrossRef]

184. Dalic, L.; Cook, M.J. Managing drug-resistant epilepsy: Challenges and solutions. Neuropsychiatr. Dis. Treat. 2016, 12, 2605-2616. [CrossRef] [PubMed]

185. Huguenard, J.R. Block of T -Type Ca(2+) Channels Is an Important Action of Succinimide Antiabsence Drugs. Epilepsy Curr. 2002, 2, 49-52. [CrossRef] [PubMed]

186. Gomora, J.C.; Daud, A.N.; Weiergraber, M.; Perez-Reyes, E. Block of cloned human T-type calcium channels by succinimide antiepileptic drugs. Mol. Pharmacol. 2001, 60, 1121-1132. [CrossRef] [PubMed]

187. Crunelli, V.; Leresche, N. Block of Thalamic T-Type Ca(2+) Channels by Ethosuximide Is Not the Whole Story. Epilepsy Curr. 2002, 2, 53-56. [CrossRef]

188. Goren, M.Z.; Onat, F. Ethosuximide: From bench to bedside. CNS Drug Rev. 2007, 13, 224-239. [CrossRef] [PubMed]

189. Terzioglu, B.; Aypak, C.; Onat, F.Y.; Kucukibrahimoglu, E.; Ozkaynakci, A.E.; Goren, M.Z. The effects of ethosuximide on amino acids in genetic absence epilepsy rat model. J. Pharmacol. Sci. 2006, 100, 227-233. [CrossRef]

190. Ziyatdinova, S.; Gurevicius, K.; Kutchiashvili, N.; Bolkvadze, T.; Nissinen, J.; Tanila, H.; Pitkanen, A. Spontaneous epileptiform discharges in a mouse model of Alzheimer's disease are suppressed by antiepileptic drugs that block sodium channels. Epilepsy Res. 2011, 94, 75-85. [CrossRef] 
191. Matar, N.; Jin, W.; Wrubel, H.; Hescheler, J.; Schneider, T.; Weiergraber, M. Zonisamide block of cloned human T-type voltage-gated calcium channels. Epilepsy Res. 2009, 83, 224-234. [CrossRef] [PubMed]

192. Tanabe, M.; Murakami, T.; Ono, H. Zonisamide suppresses pain symptoms of formalin-induced inflammatory and streptozotocininduced diabetic neuropathy. J. Pharmacol. Sci. 2008, 107, 213-220. [CrossRef] [PubMed]

193. Tringham, E.; Powell, K.L.; Cain, S.M.; Kuplast, K.; Mezeyova, J.; Weerapura, M.; Eduljee, C.; Jiang, X.; Smith, P.; Morrison, J.L.; et al. T-type calcium channel blockers that attenuate thalamic burst firing and suppress absence seizures. Sci. Transl. Med. 2012, 4, 121ra19. [CrossRef]

194. Johannessen Landmark, C.; Beiske, G.; Baftiu, A.; Burns, M.L.; Johannessen, S.I. Experience from therapeutic drug monitoring and gender aspects of gabapentin and pregabalin in clinical practice. Seizure 2015, 28, 88-91. [CrossRef]

195. Radzicki, D.; Yau, H.J.; Pollema-Mays, S.L.; Mlsna, L.; Cho, K.; Koh, S.; Martina, M. Temperature-sensitive Cav1.2 calcium channels support intrinsic firing of pyramidal neurons and provide a target for the treatment of febrile seizures. J. Neurosci. 2013, 33, 9920-9931. [CrossRef] [PubMed]

196. Furukawa, T.; Nukada, T.; Namiki, Y.; Miyashita, Y.; Hatsuno, K.; Ueno, Y.; Yamakawa, T.; Isshiki, T. Five different profiles of dihydropyridines in blocking T-type $\mathrm{Ca}(2+)$ channel subtypes $(\mathrm{Ca}(\mathrm{v}) 3.1$ (alpha(1G)), $\mathrm{Ca}(\mathrm{v}) 3.2(\mathrm{alpha}(1 \mathrm{H}))$, and $\mathrm{Ca}(\mathrm{v}) 3.3$ (alpha(1I))) expressed in Xenopus oocytes. Eur. J. Pharmacol. 2009, 613, 100-107. [CrossRef]

197. Chang, S.Y.; Yong, T.F.; Yu, C.Y.; Liang, M.C.; Pletnikova, O.; Troncoso, J.; Burgunder, J.M.; Soong, T.W. Age and gender-dependent alternative splicing of P/Q-type calcium channel EF-hand. Neuroscience 2007, 145, 1026-1036. [CrossRef] [PubMed]

198. Michailidis, I.E.; Abele-Henckels, K.; Zhang, W.K.; Lin, B.; Yu, Y.; Geyman, L.S.; Ehlers, M.D.; Pnevmatikakis, E.A.; Yang, J. Age-related homeostatic midchannel proteolysis of neuronal L-type voltage-gated $\mathrm{Ca}(2)(+)$ channels. Neuron 2014, 82, $1045-1057$. [CrossRef] [PubMed]

199. Qian, H.; Patriarchi, T.; Price, J.L.; Matt, L.; Lee, B.; Nieves-Cintron, M.; Buonarati, O.R.; Chowdhury, D.; Nanou, E.; Nystoriak, M.A.; et al. Phosphorylation of Ser1928 mediates the enhanced activity of the L-type $\mathrm{Ca}^{2+}$ channel Cav1.2 by the beta2-adrenergic receptor in neurons. Sci. Signal. 2017, 10, eaaf9647. [CrossRef] [PubMed]

200. Davare, M.A.; Hell, J.W. Increased phosphorylation of the neuronal L-type $\mathrm{Ca}(2+)$ channel Ca(v)1.2 during aging. Proc. Natl. Acad. Sci. USA 2003, 100, 16018-16023. [CrossRef] [PubMed]

201. Folci, A.; Steinberger, A.; Lee, B.; Stanika, R.; Scheruebel, S.; Campiglio, M.; Ramprecht, C.; Pelzmann, B.; Hell, J.W.; Obermair, G.J.; et al. Molecular mimicking of C-terminal phosphorylation tunes the surface dynamics of CaV1.2 calcium channels in hippocampal neurons. J. Biol. Chem. 2018, 293, 1040-1053. [CrossRef] [PubMed] 